Prepared in Cooperation with the U.S. Army Corps of Engineers

Mercury in Waters, Soils, and Sediments of the New Jersey Coastal Plain: A Comparison of Regional Distribution and Mobility with the Mercury Contamination at the William J. Hughes Technical Center, Atlantic County, New Jersey

Scientific Investigations Report 2012-5115 



\section{Mercury in Waters, Soils, and Sediments of the New Jersey Coastal Plain: A Compari- son of Regional Distribution and Mobility with the Mercury Contamination at the William J. Hughes Technical Center, Atlantic County, New Jersey}

By Julia L. Barringer, Zoltan Szabo, and Pamela A. Reilly

Prepared in cooperation with the

U.S. Army Corps of Engineers

Scientific Investigations Report 2012-5115 


\section{U.S. Department of the Interior \\ KEN SALAZAR, Secretary \\ U.S. Geological Survey \\ Marcia K. McNutt, Director}

\section{U.S. Geological Survey, Reston, Virginia: 2012}

For more information on the USGS - the Federal source for science about the Earth, its natural and living resources, natural hazards, and the environment, visit http://www.usgs.gov or call 1-888-ASK-USGS.

For an overview of USGS information products, including maps, imagery, and publications, visit http://www.usgs.gov/pubprod

To order this and other USGS information products, visit http://store.usgs.gov

Any use of trade, product, or firm names is for descriptive purposes only and does not imply endorsement by the U.S. Government.

Although this report is in the public domain, permission must be secured from the individual copyright owners to reproduce any copyrighted materials contained within this report.

Suggested citation:

Barringer, J.L., Szabo, Zoltan, and Reilly, P.A., 2012, Mercury in waters, soils, and sediments of the New Jersey Coastal Plain: A comparison of regional distribution and mobility with the mercury contamination at the William J. Hughes Technical Center, Atlantic County, New Jersey: U.S. Geological Survey Scientific Investigations Report 2012-5115, $34 \mathrm{p}$. 


\section{Acknowledgments}

The authors thank Gregory Goepfert, Tracy Dorgan, and James Kelly of the U.S Army Corps of Engineers for providing the funding for this overview of the mercury studies in New Jersey. Thanks go to Ryan Brown of Weston Solutions for supplying documentation of the studies at the William J. Hughes Technical Center site.

\section{Contents}

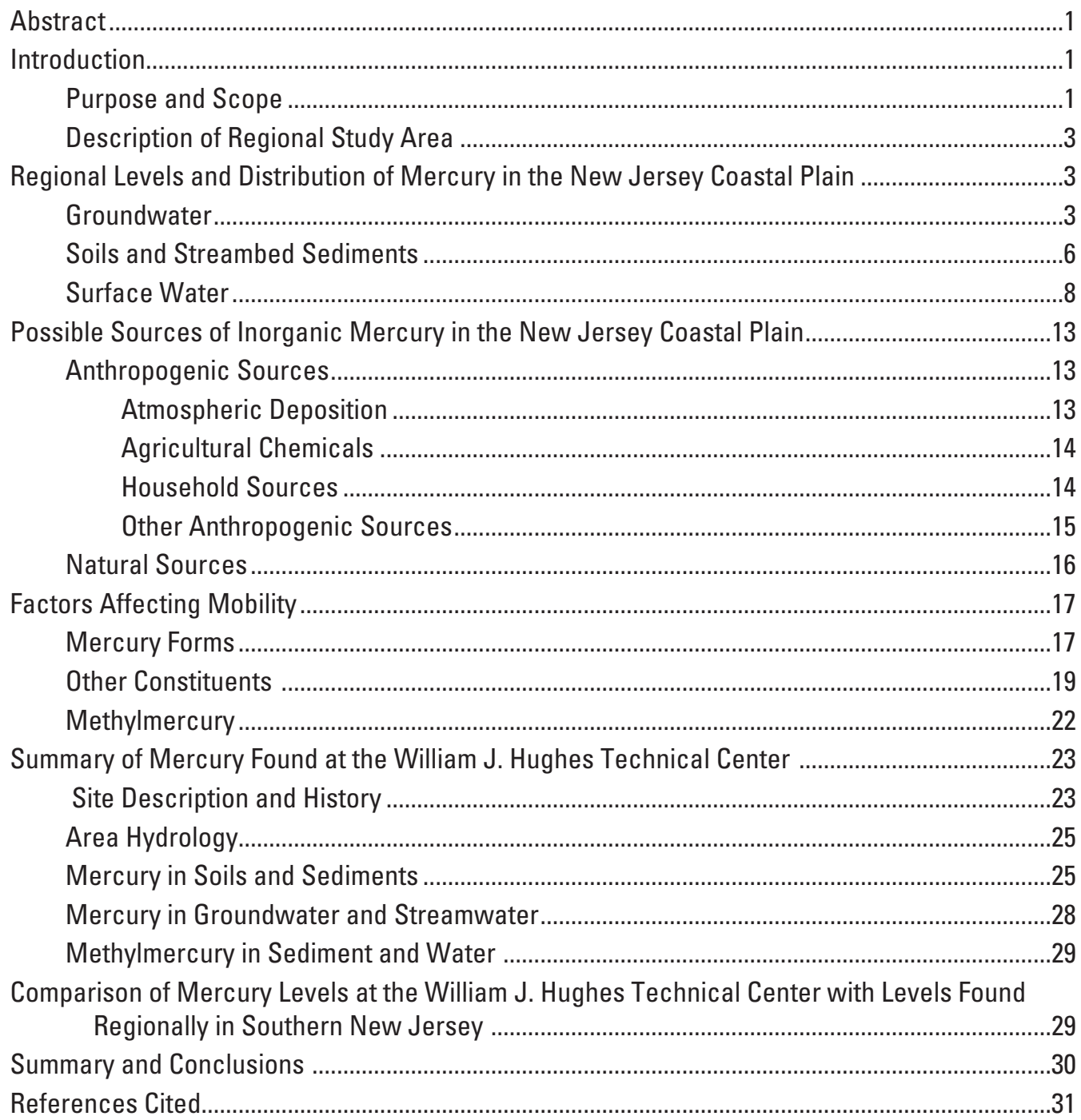




\section{Figures}

1. Map showing outcrop areas of the sediments of Miocene age that compose the Kirkwood-Cohansey aquifer system, overlying Pleistocene sediments of the Cape May Formation, and location of the William J. Hughes Technical Center, the Burlington County site, the Franklin Township site, the Squankum Branch watershed, and domestic well SUSCP30 in the New Jersey Coastal Plain..

2. Map showing location of regional study area, extent of Pine Barrens in New Jersey, now referred to as Pinelands, and an idealized vertical section through the Kirkwood-Cohansey aquifer system showing regional groundwater flow.

3. Map showing location of Squankum Branch, tributary to the Great Egg Harbor River, and its watershed, showing 1930s land use, recent (2008-09) streamwater and sediment sampling sites, and site of residential area where groundwater from the Kirkwood-Cohansey aquifer system was found in the 1990s to contain contaminant levels of mercury ...

4. Map showing land use (2002) within the non-tidal part of the Great Egg Harbor River watershed and Hammonton Creek watershed in New Jersey, with sampling sites from the U.S. Geological Survey 2006-08 investigations of mercury and methylmercury in the watersheds.

5. Graph showing concentrations of total mercury in unfiltered and filtered water collected throughout the day from domestic well 051789 completed in the Kirkwood-Cohansey aquifer system, Burlington County, New Jersey, June, 2009.

6. Graphs showing concentrations of (a) nitrate, (b) dissolved oxygen, (c) mercury, (d) iron, and (e) dissolved organic carbon, and (f) $\mathrm{pH}$ in groundwater samples from the Kirkwood-Cohansey aquifer system, collected at discrete intervals with a screened augur, showing increase of iron and mercury concentrations with onset of reducing conditions downgradient from an abandoned septic leach field, Franklin Township, Gloucester County, New Jersey

7. Map showing location of Atlantic City International Airport, which encompasses the William J. Hughes Technical Center and Area U, from TRC, 2005, with overlay of residential areas with mercury-contaminated groundwater from the KirkwoodCohansey aquifer system, shown in Barringer and others, 1997.

8. Graph showing time line indicating various events at and in the vicinity of the William J. Hughes Technical Center site, New Jersey.

9. Map showing concentrations of mercury in groundwater from domestic wells completed in the Kirkwood-Cohansey aquifer system at a residential area (site 2) to the southwest of the William J. Hughes Technical Center site, Atlantic County, New Jersey, and direction of the horizontal component of groundwater flow determined from water-level data.

10. Map showing area surrounding the Atlantic City International Airport in New Jersey, which encompasses the William J. Hughes Technical Center site, groundwaterflow directions in the Kirkwood-Cohansey aquifer system, and six residential sites where domestic wells yielded water containing total mercury at concentrations that approached or exceeded the New Jersey maximum contaminant level of 2 micrograms per liter. 


\section{Tables}

1. Contents of selected trace elements determined by total digestion and organic carbon in core samples of Kirkwood-Cohansey aquifer-system sediments from wells installed along rights-of-way in Williamstown, in the Great Egg Harbor River watershed, Gloucester County, New Jersey.....

2. Contents of trace elements in aquifer sediments from core samples from Squankum Branch, Gloucester County, New Jersey, 2009

3A. Contents of recoverable mercury, streambed sediments from Hammonton Creek and the Great Egg Harbor River and tributaries, Gloucester and Atlantic Counties, New Jersey, 2006-07.

3B. Values of $\mathrm{pH}$ and concentrations of total mercury and methylmercury in unfiltered and filtered samples of streamwater from Hammonton Creek and the Great Egg Harbor River and tributaries, Gloucester and Atlantic Counties, New Jersey, 2006-07.

4. Concentrations of selected constituents and values of $\mathrm{pH}$ in backwash brines from household water-treatment systems at three domestic wells in Burlington County, New Jersey, 2008-09.

5. Field properties, concentrations of total mercury, and dissolved major and trace constituents in well water from domestic well SUSCP30 in cranberry bog area in New Jersey, 1998 and 2006.

6. Concentrations of particulate mercury and mercury in unfiltered and filtered samples of domestic-well water collected throughout a day to simulate normal household water use, Burlington County, New Jersey, 2008-09.

7. Contents of selected constituents in B-horizon soils from Burlington County, New Jersey, and concentrations of mercury and selected constituents and $\mathrm{pH}$ in leaching solutions and leachate from column experiments.

8. Summary of similarities and dissimilarities between mercury levels at the William J. Hughes Technical Center and regionally in the Coastal Plain of New Jersey. 


\section{Conversion Factors}

\begin{tabular}{|c|c|c|}
\hline Multiply & By & To obtain \\
\hline \multicolumn{3}{|c|}{ Length } \\
\hline inch (in.) & 2.54 & centimeter $(\mathrm{cm})$ \\
\hline inch (in.) & 25.4 & millimeter $(\mathrm{mm})$ \\
\hline foot $(\mathrm{ft})$ & 0.305 & meter $(\mathrm{m})$ \\
\hline mile (mi) & 1.609 & kilometer (km) \\
\hline yard (yd) & 0.914 & meter $(\mathrm{m})$ \\
\hline \multicolumn{3}{|c|}{ Area } \\
\hline square mile $\left(\mathrm{mi}^{2}\right)$ & 2.59 & square kilometer $\left(\mathrm{km}^{2}\right)$ \\
\hline \multicolumn{3}{|c|}{ Volume } \\
\hline barrel (bbl), (petroleum, 1 barrel = 42 gal) & 0.159 & cubic meter $\left(\mathrm{m}^{3}\right)$ \\
\hline ounce, fluid (fl. oz) & 0.030 & liter $(\mathrm{L})$ \\
\hline pint (pt) & 0.473 & liter (L) \\
\hline quart (qt) & 0.946 & liter (L) \\
\hline gallon (gal) & 3.785 & liter $(\mathrm{L})$ \\
\hline \multicolumn{3}{|c|}{ Flow rate } \\
\hline cubic foot per second $\left(\mathrm{ft}^{3} / \mathrm{s}\right)$ & 0.028 & $\begin{array}{l}\text { cubic meter per second } \\
\qquad\left(\mathrm{m}^{3} / \mathrm{s}\right)\end{array}$ \\
\hline
\end{tabular}

Temperature in degrees Celsius $\left({ }^{\circ} \mathrm{C}\right)$ may be converted to degrees Fahrenheit $\left({ }^{\circ} \mathrm{F}\right)$ as follows:

${ }^{\circ} \mathrm{F}=\left(1.8 \mathrm{x}^{\circ} \mathrm{C}\right)+32$

Temperature in degrees Fahrenheit $\left({ }^{\circ} \mathrm{F}\right)$ may be converted to degrees Celsius $\left({ }^{\circ} \mathrm{C}\right)$ as follows:

${ }^{\circ} \mathrm{C}=\left({ }^{\circ} \mathrm{F}-32\right) / 1.8$

Horizontal coordinate information is referenced to the North American Datum of 1983 (NAD 83).

Vertical coordinate information is referenced either to the North American Vertical Datum of 1988 (NAVD 88), or, for the earliest studies cited, to the National Geodetic Vertical Datum of 1929.

Specific conductance is given in microsiemens per centimeter at 25 degrees Celsius $\left(\mu \mathrm{S} / \mathrm{cm}\right.$ at $\left.25^{\circ} \mathrm{C}\right)$.

Concentrations of chemical constituents in water are given either in milligrams per liter $(\mathrm{mg} / \mathrm{L})$, which is equivalent to parts per million; or micrograms per liter $(\mu \mathrm{g} / \mathrm{L})$, which is equivalent to parts per billion.

Concentrations of chemical constituents in soils are given in milligrams per kilogram $(\mathrm{mg} / \mathrm{kg})$, which is equivalent to parts per million. 


\section{Chemical Abbreviations}

\begin{tabular}{|c|c|}
\hline As & Arsenic \\
\hline $\mathrm{Ca}$ & Calcium \\
\hline $\mathrm{Cl}^{-}$ & Chloride \\
\hline DO & Dissolved oxygen \\
\hline DOC & Dissolved organic carbon \\
\hline $\mathrm{Fe}$ & Iron \\
\hline $\mathrm{Hg}$ & Mercury \\
\hline K & Potassium \\
\hline MBAS & Methylene blue active substances \\
\hline $\mathrm{Mg}$ & Magnesium \\
\hline $\mathrm{Mn}$ & Manganese \\
\hline $\mathrm{N}$ & Nitrogen \\
\hline $\mathrm{Na}$ & Sodium \\
\hline $\mathrm{NH}_{4}^{+}$ & Ammonium \\
\hline $\mathrm{NO}_{3}^{-}$ & Nitrate \\
\hline $\mathrm{NO}_{2}^{-}$ & Nitrite \\
\hline$P$ & Phosphorus \\
\hline $\mathrm{Pb}$ & Lead \\
\hline SC & Specific conductance \\
\hline $\mathrm{SO}_{4}^{2-}$ & Sulfate \\
\hline $\mathrm{T}$ & Temperature \\
\hline${ }^{137} \mathrm{Cs}$ & Cesium-137 \\
\hline${ }^{210} \mathrm{~Pb}$ & Lead-210 \\
\hline
\end{tabular}

\section{Acronyms}

$\begin{array}{ll}\text { CKKD } & \text { Kirkwood-Cohansey aquifer system } \\ \text { FAA } & \text { Federal Aviation Administration } \\ \text { NBAC } & \text { North Branch Absecon Creek } \\ \text { NJDEP } & \text { New Jersey Department of Environmental Protection } \\ \text { SBAC } & \text { South Branch Absecon Creek } \\ \text { USGS } & \text { U.S. Geological Survey } \\ \text { WHJTC } & \text { William J. Hughes Technical Center }\end{array}$





\title{
Mercury in Waters, Soils, and Sediments of the New Jersey Coastal Plain: A Comparison of Regional Distribution and Mobility with the Mercury Contamination at the William J. Hughes Technical Center, Atlantic County, New Jersey
}

\author{
Julia L. Barringer, Zoltan Szabo, and Pamela A. Reilly
}

\begin{abstract}
Mercury in soils, surface water, and groundwater at the William J. Hughes Technical Center, Atlantic County, New Jersey, has been found at levels that exceed established background concentrations in Coastal Plain waters, and, in some cases, New Jersey State standards for mercury in various media. As of 2012, it is not known whether this mercury is part of regional mercury contamination or whether it is related to former military activities. Regionally, groundwater supplying about 700 domestic wells in the New Jersey Coastal Plain is contaminated with mercury that appears to be derived from anthropogenic inputs, such as agricultural pesticide use and atmospheric deposition. High levels of mercury occasionally are found in Coastal Plain soils, but disturbance during residential development on former agricultural land is thought to have mobilized any mercury applied during farming, a hypothesis borne out by experiments leaching mercury from soils. In the unsewered residential areas with mercury-contaminated groundwater, septic-system effluent is believed to create reducing conditions in which mercury sorbed to subsoils is mobilized to groundwater.

In comparing the levels of mercury found in soils, sediments, streamwater, and groundwater at the William J. Hughes Technical Center site with those found regionally, mercury concentrations in groundwater in the region are, in some cases, substantially higher than those found in groundwater at the William J. Hughes Technical Center site. Nevertheless, concentrations of mercury in streamwater at the site are, in some instances, higher than most found regionally. The mercury contents in soils and sediment at the William J. Hughes Technical Center site are substantially higher than those found to date (2012) in the region, indicating that a source other than regional sources may be present at the site.
\end{abstract}

\section{Introduction}

Mercury ( $\mathrm{Hg}$ ) has been found at the William J. Hughes Technical Center (WJHTC) Superfund site in Atlantic County, New Jersey (fig. 1), at levels that exceed the background concentrations in Coastal Plain waters, soils, and sediments; past and recent investigations by the U.S. Geological Survey (USGS) and the New Jersey Department of Environmental Protection (NJDEP) illustrated the likely ranges of naturally occurring and background levels of mercury in these media. Streamwater concentrations at this site have, in some instances, exceeded the State Surface Water Quality Standard of 0.05 microgram per liter $(\mu \mathrm{g} / \mathrm{L}$; New Jersey Department of Environmental Protection, 2010). Groundwater in parts of the site contains $\mathrm{Hg}$ at concentrations that exceed the State maximum contaminant level (MCL) of $2 \mu \mathrm{g} / \mathrm{L}$ (New Jersey Department of Environmental Protection, 2005). Whether the mercury is associated with contamination dating from the use of the site by the U.S. Navy, whether it represents part of a southern New Jersey regional problem with Hg contamination, or some combination of both, is currently (2012) being investigated. As part of the investigation, by the U.S. Army Corps of Engineers, the USGS has summarized results of regional studies of mercury and the findings for the WJHTC, and compared the latter with findings from the previous studies of mercury in the New Jersey Coastal Plain.

\section{Purpose and Scope}

The purpose of this report is to (1) review the existing data on mercury in water, soils, and sediments of the New Jersey Coastal Plain, (2) summarize the interpretations of those data with respect to mercury sources and causes of mobility, and (3) discuss the findings of mercury at the William J. Hughes Technical Center, Atlantic County, New Jersey, in light of the existing Coastal Plain area studies. 


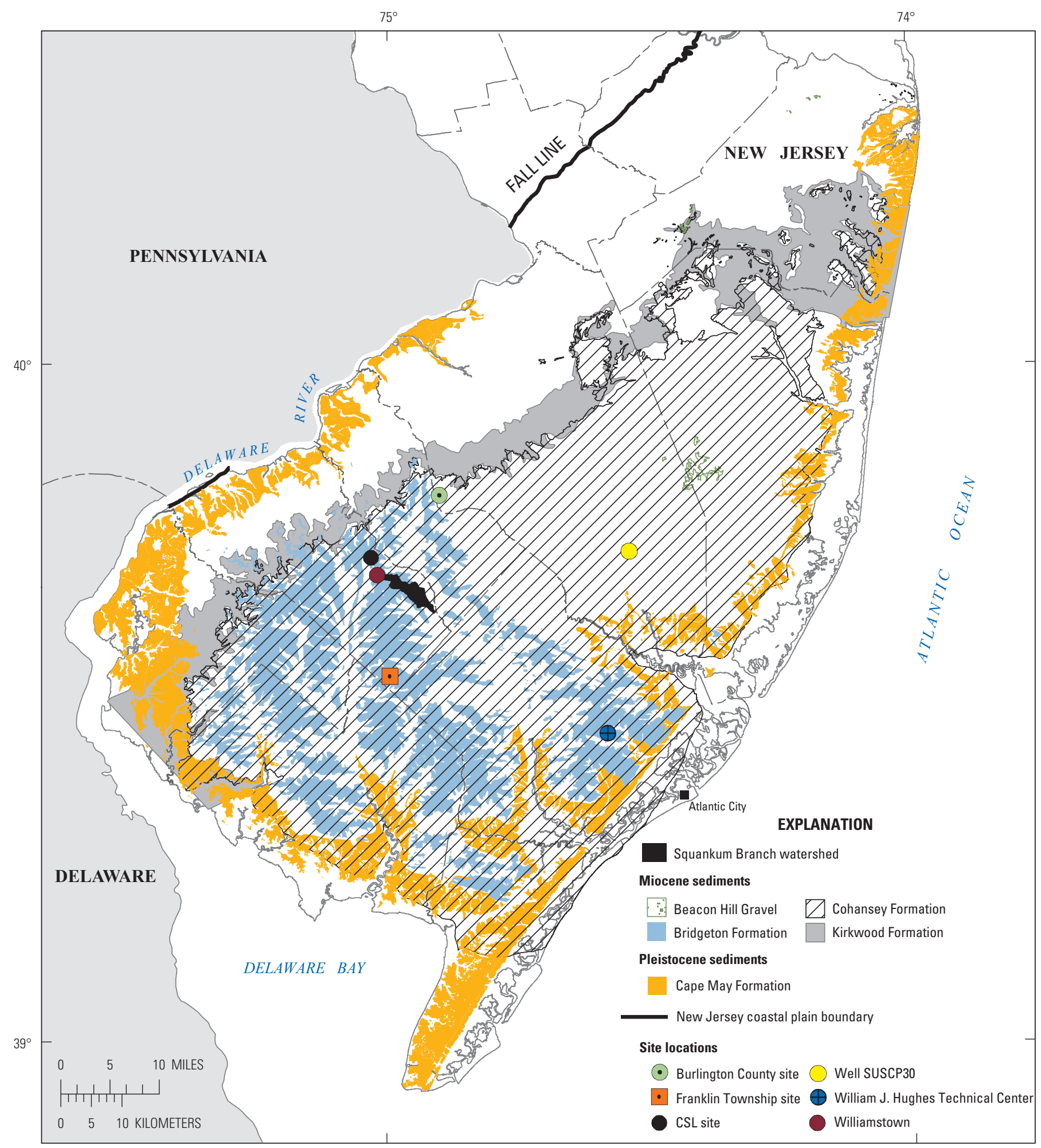

Base from U.S. Geological Survey digital line graph files, 1:24,000,

Universal Transverse Mercator projection, Zone 18, NAD 83

Figure 1. Outcrop areas of the sediments of Miocene age that compose the Kirkwood-Cohansey aquifer system, overlying Pleistocene sediments of the Cape May Formation, and location of the William J. Hughes Technical Center, the Burlington County site, the Franklin Township site, the Squankum Branch watershed, and domestic well SUSCP30 in the New Jersey Coastal Plain. 
The report is composed of five main sections. The first section is a summary of the levels and distribution of $\mathrm{Hg}$ in the Coastal Plain region. The second section is a summary of likely sources determined from existing regional and local studies. The third section presents a discussion of factors affecting $\mathrm{Hg}$ mobility. The fourth section presents the available data on methyl mercury ( $\mathrm{MeHg}$ ) in the New Jersey Coastal Plain, and the fifth section is a brief summary of major findings from the WJHTC and a comparison of those results with results from previous regional and local studies.

\section{Description of Regional Study Area}

The New Jersey Coastal Plain is a seaward-thickening wedge of sediments deposited during parts of the Mesozoic and Cenozoic Eras; sediments range in age from the Cretaceous through the Miocene periods with a spatially scattered veneer of younger (Pleistocene and Holocene) deposits (fig. 1). The uppermost part of the wedge is composed of quartzose sands and gravels of the Cohansey and Kirkwood Formations, deposited in near-shore and deltaic environments during the Miocene Epoch. Scattered outcrops of the Late Miocene Beacon Hill Gravel and Bridgeton Formation overlie the Cohansey Formation in some upland areas. Together, these four formations form the most areally extensive (3,000 square miles $\left(\mathrm{mi}^{2}\right)$ ), and mostly unconfined, aquifer system of the New Jersey Coastal Plain - the Kirkwood-Cohansey aquifer system (CKKD; Zapecza, 1989). This system is about 250 to 300 feet (ft) thick in the WJHTC study area.

Recharge to the system is provided by precipitation, of which about 50 percent is returned to the atmosphere by transpiration and evaporation (Rhodehamel, 1979). Recharge in upland areas near topographic divides tends to move deeply into the aquifer system (fig. 2); groundwater at depth may be recharge that is hundreds to several thousands of years old. Streams and wetlands typically are in groundwater discharge areas, with small streams receiving local, relatively young water and major streams receiving deeper, older water. In the 1970s, Rhodehamel (1979) estimated that 89 percent of streamflow is derived from groundwater discharge (base flow). With recent development leading to greater groundwater withdrawals, this estimated percentage likely has decreased.

Groundwater typically is acidic, with a median $\mathrm{pH}$ of 4.4 found in 13 samples collected from wells in undeveloped areas. With increasing agricultural and (or) residential development, groundwater $\mathrm{pH}$ tends to change, often increasing (see Table III, Barringer and Szabo, 2006), particularly as agricultural chemicals (primarily lime, in the form of dolomite (CaMg (CO3)2) enter the aquifer system. Streamwater also is acidic. In the streamwater, $\mathrm{pH}$ values vary, particularly in wetlands areas; $\mathrm{pH}$ is higher during dry periods when base flow is dominant and lower during wet periods when acidic water from the wetlands is flushed into the streams (Barringer and others, 2010a).

The sandy soils developed on the CKKD sediments are acidic to strongly acidic and are well drained to excessively drained in upland areas; they typically contain little organic matter (Markley, 1979). Natural, undisturbed upland soils comprise several soils series with similar characteristics; these typically contain an organic-rich surface layer (O horizon) underlain by a strongly leached, sandy, mineral soil layer (A horizon) underlain by a layer that, in some series, is an E horizon. The A (and $\mathrm{E}$ ) horizons, in turn, are underlain by thick zones where leached materials accumulate (B horizon); the B-horizon soils are mainly composed of iron-hydroxide-coated sands and clays. The $\mathrm{B}$ horizon grades into the $\mathrm{C}$ horizon, which is composed of barely altered geologic substrate. Along streams and in wetlands areas, an illuviated sediment layer may be found at the water table, and soils tend to be relatively rich in organic matter and generally are poorly drained.

With displacement of native populations and settlement by people of English and European origin in the 17th and 18th centuries, southern New Jersey became a largely agrarian economy (Schmidt, 1973), although glass-blowing, lumbering, charcoal-roasting, and iron-smelting and forging industries were present (Wacker, 1979) in areas that are now mostly part of the Pinelands (formerly known as the Pine Barrens (fig. 2; Rhodehamel, 1979)). Although cities grew, agriculture remained an important industry through the 19th and into the 20th centuries (Schmidt, 1973). With the end of World War II, however, residential development increasingly began to supplant agriculture as an important land use. Much of southern New Jersey currently (2012) is a mosaic of land uses and land covers. The region still includes areas of forests and wetlands, some of which are protected in State Forests and Preserves and some of which are now adjacent to residential areas.

Most areas of the Coastal Plain underlain by CKKD sediments have been investigated in USGS and NJDEP mercury studies, with the exception of the lower Cape May peninsula. There the CKKD does not have direct connection to land surface because it is confined by the younger sediments overlying it. The WJHTC site is located in Atlantic County; about 6 miles (mi) from the Atlantic coast (fig. 1).

\section{Regional Levels and Distribution of Mercury in the New Jersey Coastal Plain}

The following section reviews the existing data on $\mathrm{Hg}$ in the environment of southern New Jersey. Concentrations in groundwater and streamwater, and contents of soils and streambed sediments, are presented and discussed.

\section{Groundwater}

Regional Hg contamination in southern New Jersey primarily affects potable water sources. In the Coastal Plain of southern New Jersey, groundwater is a major source of drinking water; about 62,000 private domestic wells (Jennifer 

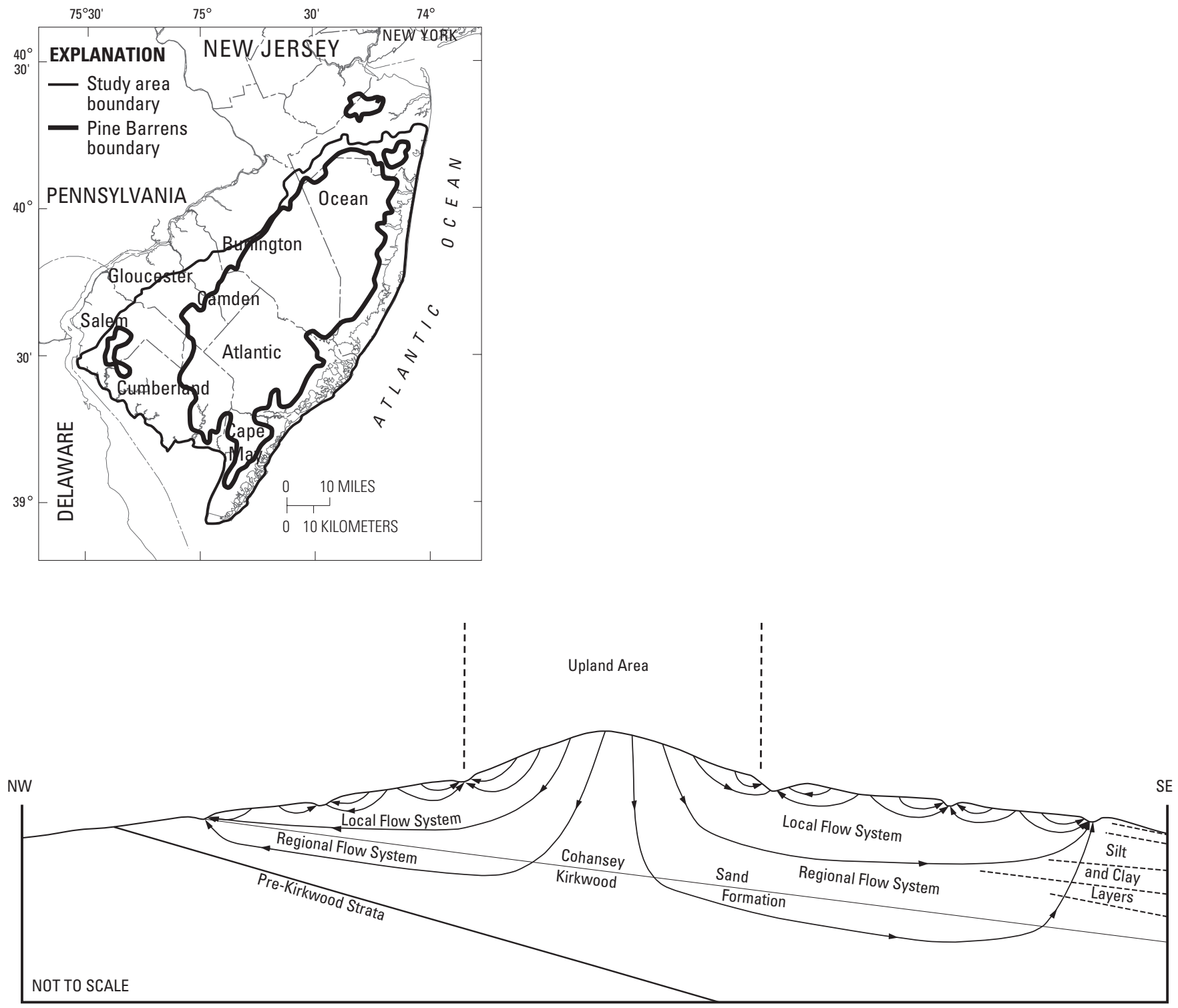

Figure 2. Location of regional study area, extent of Pine Barrens in New Jersey, now referred to as Pinelands, and an idealized vertical section through the Kirkwood-Cohansey aquifer system showing regional groundwater flow. (Bridgeton Formation and Beacon Hill Gravel are not shown. Vertical section from Rhodehamel, 1970) 
Bonin, U.S. Geological Survey, written commun., 2011) supply much of the water to residential areas. Since the early 1980s, water from some of the domestic wells completed in the CKKD (fig. 1) has been found to contain total mercury $(\mathrm{THg})$ - inorganic and, if present, organic forms - at levels that exceed $1 \mu \mathrm{g} / \mathrm{L}$ but not $2 \mu \mathrm{g} / \mathrm{L}$ (herein referred to as "elevated" levels); more importantly, there are numerous examples of mainly unfiltered well-water samples containing THg at concentrations that exceed the MCL of $2 \mu \mathrm{g} / \mathrm{L}$ (herein referred to as "contaminant levels" (see Barringer and others, 1997)). Since the discovery of contaminant levels of THg in groundwater in the New Jersey Coastal Plain, Hg-contaminated groundwater in a Coastal Plain aquifer has been found at a site in Delaware (Koterba and others, 2006).

Although the number of wells that have or are producing Hg-contaminated water in southern New Jersey is not known with accuracy, estimates place the number at about 700 . To date (2012), this number appears to represent from 0.5 to 1 percent of the wells tested for $\mathrm{Hg}$ levels in southern New Jersey; the rest have yielded water with THg concentrations less than the MCL. For those wells that produced water with THg concentrations at or greater than the MCL, concentrations in unfiltered water samples have been as high as $81 \mu \mathrm{g} / \mathrm{L}$ (Dr. Judith Louis, New Jersey Department of Environmental Protection, oral commun., 2010), although concentrations have been found to change over time (see table 8 in Barringer and others, 1997). One well in Atlantic County yielded unfiltered water with $\mathrm{THg}$ concentrations that ranged from 19.0 to $72.0 \mu \mathrm{g} / \mathrm{L}$ over nearly a year of sampling; the penultimate sample with $72.0 \mu \mathrm{g} / \mathrm{L}$ was succeeded on the following day by a sample containing $2.2 \mu \mathrm{g} / \mathrm{L}$ of THg (Barringer and others, 1997). In general, for wells sampled over months to years, the $\mathrm{THg}$ concentrations can vary widely. For those wells that yielded water with concentrations less than the MCL or not detected at 0.2 or $0.1 \mu \mathrm{g} / \mathrm{L}$ (the common detection limits of the commercial laboratories used during the 1980s and 1990s), it seldom has been known whether concentrations increased over time because those wells were not repeatedly sampled as part of the routine followed by State or county agencies. Recent sampling of wells by NJDEP at a residential area in Burlington County has included re-sampling of wells yielding water with $\mathrm{THg}$ at concentrations less than the MCL; however, for a few wells, the data indicate that concentrations have risen (Robert A. Gallagher, New Jersey Department of Environmental Protection, written commun., 2009).

In water from the CKKD, THg concentrations of $1 \mu \mathrm{g} / \mathrm{L}$ were much greater than background concentrations of $\mathrm{THg}$, which have been found to be $0.010 \mu \mathrm{g} / \mathrm{L}$ or less in studies where analytical detection limits of less than $0.01 \mu \mathrm{g} / \mathrm{L}$ were available (Windom and Smith, 1992; Barringer and others 2005; Barringer and Szabo, 2006). Anthropogenic effects on water quality (greater than background concentrations of chloride $\left(\mathrm{Cl}^{-}\right)$and nutrients, for example) were seen in wellwater samples with $\mathrm{THg}$ concentrations that were greater than $0.10 \mu \mathrm{g} / \mathrm{L}$ (Barringer and others, 2005). Where THg concentrations exceeded $0.010 \mu \mathrm{g} / \mathrm{L}$ but were less than the MCL, THg probably did not occur naturally but likely was the result of anthropogenic inputs and (or) mobilization through changes to the geochemical environment by human activities and chemical inputs.

Concentrations of THg as high as 72 or $81 \mu \mathrm{g} / \mathrm{L}$ in domestic well water apparently occurred rarely, but numerous concentrations greater than $10 \mu \mathrm{g} / \mathrm{L}$ are reported in the compilation of analytical results from the 1980s and 1990s in Barringer and others (1997). Concentrations of 2 to $10 \mu \mathrm{g} / \mathrm{L}$ represent the most common range of MCL exceedences in that database.

The sampling protocols used by county agencies and the NJDEP for domestic wells involve running the water for at least 15 minutes and collecting the sample directly into acidified bottles at untreated taps (either inside or outside taps) if the house had a water-treatment system. (The preferred site for sampling by USGS personnel is a tap before the pressure tank.) County agencies and the NJDEP did not filter the sample, thereby minimizing the potential for sample contamination during collection. Because repeat samples and split samples analyzed by separate laboratories returned similar results (Barringer and others, 1997), there is reason to believe that the high concentrations are not from contamination during sampling or during analysis but represent what is actually present in the aquifer. Samples collected from domestic and observation wells by the USGS since the 1990s, using ultraclean sampling techniques, confirm the existence of contaminant levels of THg in groundwater of the CKKD (see Barringer and others, 2005, 2006 and Barringer and Szabo, 2006). $\mathrm{THg}$ at contaminant levels in pre-treatment water from two public supply wells further strengthens this assessment.

Most of the domestic-well samples collected by county agencies and the NJDEP were not filtered; the USGS collected both filtered and unfiltered samples. In general, for those samples with greater than background concentrations of $\mathrm{THg}$, there were slight differences in concentrations between unfiltered and filtered samples that indicate filtering (using 0.45 micrometer $(\mathrm{mm})$ pore-size filters) removed $\mathrm{THg}$-bearing particles (Barringer and Szabo, 2006); therefore, some of the THg in groundwater was sorbed to particles.

The spatial distribution of affected wells in a given residential area is heterogeneous; a well that yielded THgcontaminated water could be adjacent to several that yielded water with undetectable THg levels, as shown by Barringer and others, 1997; Barringer and others, 2005; and Barringer and Szabo, 2006. Thus, the contamination appears to be contained in "plumelets" that move through the aquifer system over time. A study of groundwater discharge at a tributary (Squankum Branch; fig. 3) to the Great Egg Harbor River (Barringer and others, 2010b) indicated that THg-rich groundwater discharge to the stream occurred only in discrete areas along the banks of the stream, supporting the existence of the plumelets. Although attenuation of plumelets probably occurs within the aquifer, no data are currently (2012) available that conclusively support this speculation. The only supporting 


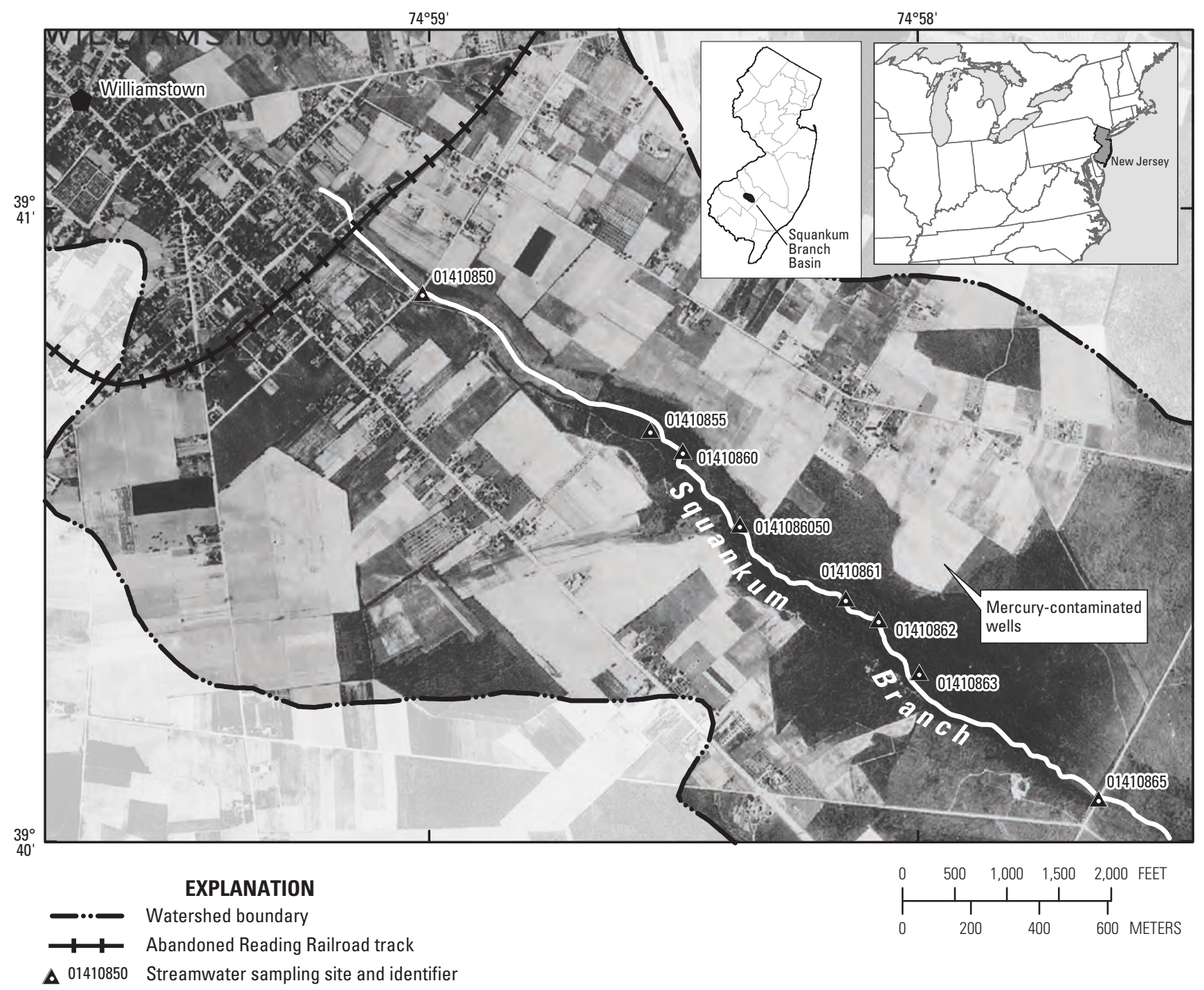

Figure 3. Location of Squankum Branch, tributary to the Great Egg Harbor River, and its watershed, showing 1930s land use, recent (2008-09) streamwater and sediment sampling sites, and site of residential area where groundwater from the Kirkwood-Cohansey aquifer system was found in the 1990s to contain contaminant levels of mercury.

evidence is the observation of decreases in $\mathrm{THg}$ concentrations over time in water from numerous wells.

Mercury at contaminant levels (defined as $>2 \mu \mathrm{g} / \mathrm{L}$ ), for the most part, has not been found in water from public supply wells, which draw water from a much larger volume of aquifer than do domestic wells. Nevertheless, a new public supply well in Cumberland County was found to yield water with $\mathrm{THg}$ concentrations that exceeded the MCL (Szabo and others, 2005 , p. 74). Water from a public supply well in Gloucester County contained contaminant levels of $\mathrm{THg}$; the water from that well is treated to remove the Hg (Richard Westergaard, Gloucester County Department of Planning, written commun., 1997). In groundwater of the New Jersey Coastal Plain, the $\mathrm{THg}$ has been found mainly in inorganic form, but studies of $\mathrm{MeHg}$ in groundwater in the affected areas are few.

\section{Soils and Streambed Sediments}

Although analyses are limited, the $\mathrm{THg}$ contents (by total digestion) of CKKD sediments were found to be less than 0.15 milligram per kilogram $(\mathrm{mg} / \mathrm{kg})$, with the highest contents present in clays, not in sands (Barringer and others, 1997; table 1). For soils developed on the CKKD sediments, background contents of THg in undisturbed forested soils probably are about 0.10 to $0.15 \mathrm{mg} / \mathrm{kg}$; the samples collected by the USGS presumably contain atmospherically deposited $\mathrm{Hg}$, in addition to $\mathrm{Hg}$ derived from the geologic substrate. In contrast, the THg contents in disturbed residential soils generally were about $0.05 \mathrm{mg} / \mathrm{kg}$ or less, which is less than background levels (Barringer and others, 1997; Barringer and Szabo, 2006). In residential-area soils, THg contents were positively related 
Table 1. Contents of selected trace elements determined by total digestion and organic carbon in core samples of KirkwoodCohansey aquifer-system sediments from wells installed along rights-of-way in Williamstown, in the Great Egg Harbor River watershed, Gloucester County, New Jersey.

[Location of Williamstown shown in figure 1. Site names are those of streets along which the wells are installed. ft bls, feet below land surface; Hg, mercury; As, arsenic; $\mathrm{Pb}$, lead; Org. C, organic carbon; mg/kg, milligrams per kilogram; \%, percent]

\begin{tabular}{|c|c|c|c|c|c|}
\hline $\begin{array}{c}\text { Site name/ } \\
\text { depth interval } \\
\text { (ft bls) }\end{array}$ & Description & $\begin{array}{c}\mathrm{Hg} \\
(\mathrm{mg} / \mathrm{kg})\end{array}$ & $\begin{array}{c}\text { As } \\
(\mathrm{mg} / \mathrm{kg})\end{array}$ & $\begin{array}{c}\mathrm{Pb} \\
(\mathrm{mg} / \mathrm{kg})\end{array}$ & $\begin{array}{c}\text { Org. C } \\
(\%)\end{array}$ \\
\hline Academy/95.1-95.5 & Quartz sand, clay, ilmenite & 0.10 & 5.40 & 10.4 & 0.28 \\
\hline Denise/29.5-29.9 & Fine quartz sand, gray clay & 0.01 & 3.80 & 2.27 & 0.09 \\
\hline Denise/108.2-108.6 & Black clay & 0.13 & 7.70 & 17.1 & 2.85 \\
\hline Oak/51.2-51.5 & Medium quartz sand, silt, mica & 0.01 & 5.90 & 2.24 & 0.14 \\
\hline Oak/83.3-84.0 & Quartz sand, clay, lignite & 0.11 & 4.90 & 19.7 & 2.06 \\
\hline Church/88.3-88.6 & Gray clay, mica & 0.06 & 3.40 & 13.3 & 0.16 \\
\hline Church/88.9-89.2 & Quartz sand, ilmenite & 0.01 & 0.50 & 9.83 & 0.08 \\
\hline
\end{tabular}

to total organic carbon contents of the A-horizon samples; however, THg contents were related to iron (Fe) contents in B-horizon samples, indicating $\mathrm{Hg}$ is complexed with organic carbon in surficial soils but apparently is sorbed to the $\mathrm{Fe}$ hydroxides that coat soil particles in the B horizon (Barringer and Szabo, 2006)

Isolated instances of $\mathrm{THg}$ contents that exceed background levels $(0.10$ to $0.15 \mathrm{mg} / \mathrm{kg})$ in soils have been found. In Franklin Township, Gloucester County at the site of a former thermometer-manufacturing facility (fig. 1), THg contents in soil ranged from 0.127 to $0.258 \mathrm{mg} / \mathrm{kg}$ (Barringer and others, 1997). The THg content was $0.153 \mathrm{mg} / \mathrm{kg}$ in a subsoil sample (orange, Fe-rich sandy B horizon) from a presumed dump area on a former farm now residentially developed in Gloucester County (the CSL site; fig.1; Barringer and others, 2006). Although the THg contents of the Gloucester County soils appear to be relatively high, they are within reported average soil $\mathrm{Hg}$ contents worldwide $(0.022-0.625 \mathrm{mg} / \mathrm{kg}$; Andersson, 1979). Grigal (2003) reports that an arithmetic mean of $0.150 \mathrm{mg} / \mathrm{kg}$ of $\mathrm{Hg}$ is found for soil in the United States, which agrees with background levels determined for the New Jersey Coastal Plain. Currently (2012), discoveries of THg contents of regional New Jersey soils that greatly exceed background levels or the average reported by Grigal (2003) are limited and instances of high levels generally remain elusive. The $\mathrm{THg}$ and acid-leachable $\mathrm{Hg}$ contents of organic-rich bankside soils of a tributary (Squankum Branch) to the Great Egg Harbor River (GEHR) near its headwaters were as high as $12.2 \mathrm{mg} / \mathrm{kg}$, however (table 2; Barringer and others, 2010b). During the 1930s, the area around the headwaters of Squankum Branch was agricultural land (fig. 3) with fields and orchards that extended to within a few hundred feet of the stream. Residential development replaced much of the agricultural land during the 1960s into the 1990s; remaining land, as of 2012, is no longer farmed and is being developed.

Streambed sediments contain weathered material from the geologic substrate, as well as soil particles brought in by runoff. Because the Coastal Plain soils, in general, are highly permeable, runoff from soils likely contributes fewer particles to the streams in the Coastal Plain than in regions with less permeable geologic substrates. Runoff from man-made impervious surfaces, however, can contribute metal-bearing particles to streams (see, for example, Barringer and others, 2010a; Barringer and others, 2011, and references therein). On the basis of existing data, the $\mathrm{THg}$ contents (from both total-digestion and recoverable (acid-leachable) analyses) of Coastal Plain streambed sediments generally are low. In the Great Egg Harbor River watershed (fig. 4), the THg contents of streambed sediments in forested areas were found to be about $0.03 \mathrm{mg} / \mathrm{kg}$ or less, but contents were greater (as much as $0.099 \mathrm{mg} / \mathrm{kg}$ ) in several areas with urban land (Barringer and others, 2010a). In the streambed sediments at Hammonton Creek (HAMM) 
Table 2. Contents of trace elements in aquifer sediments from core samples from Squankum Branch, Gloucester County, New Jersey, 2009.

[Arsenic and lead contents determined using total digestion; mercury content determined as recoverable (acid-leachable) mercury. Site numbers are shown in figure 3. USGS, U.S. Geological Survey; ft bss, feet below streambed surface; mg/kg, milligrams per kilogram; As, arsenic; $\mathrm{Hg}$, mercury; Pb, lead]

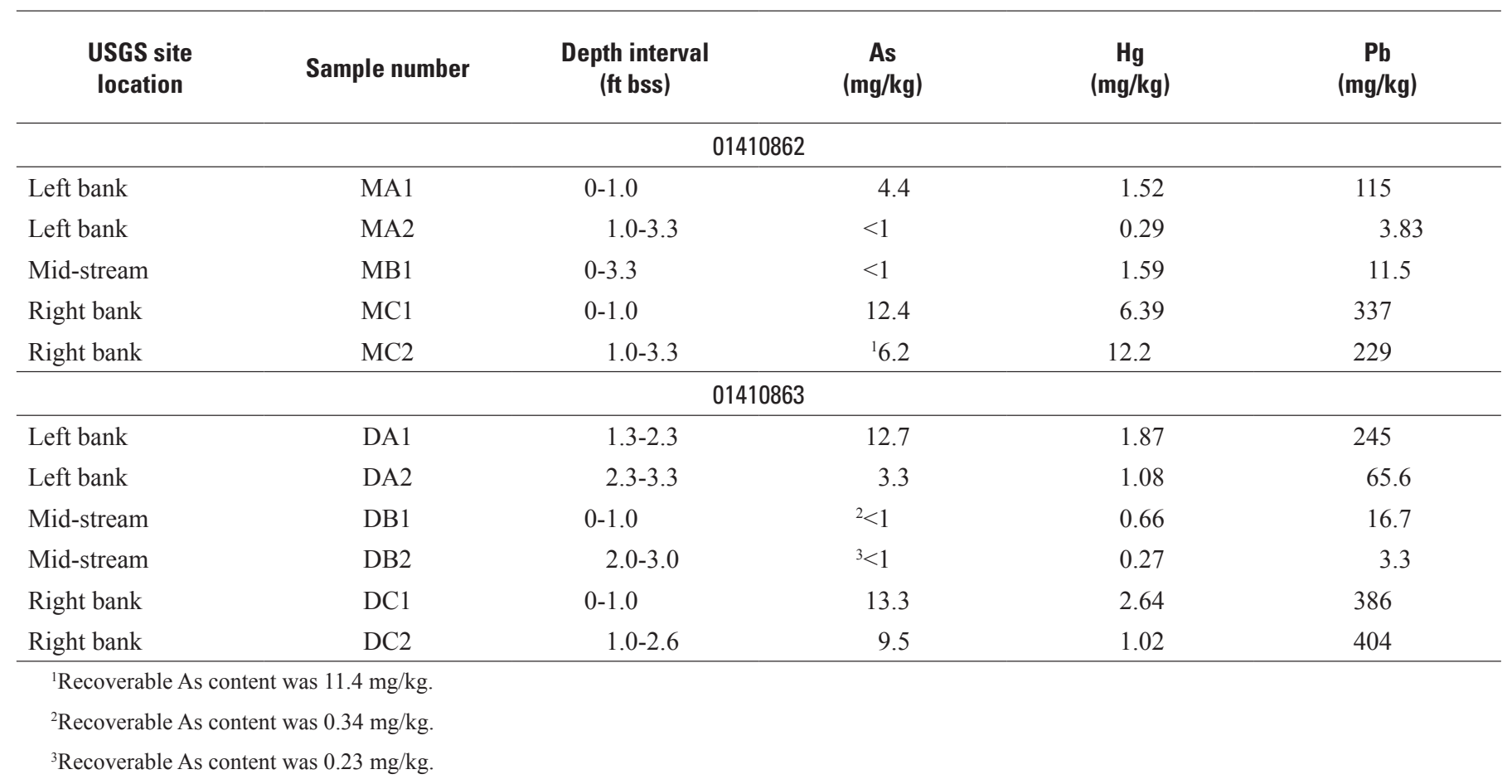

in Atlantic County (fig. 4), recoverable $\mathrm{Hg}$ contents were less than $0.035 \mathrm{mg} / \mathrm{kg}$, except for site H3 (Hammonton Creek at Hammonton, USGS site number 01409414) where trace elements and phosphorus (P) from upstream sources tended to accumulate. There, the $\mathrm{Hg}$ content was $0.238 \mathrm{mg} / \mathrm{kg}$ (table 3). At the Squankum Branch site (fig. 3) where THg contents were high (as much as $12.2 \mathrm{mg} / \mathrm{kg}$; table 2) in bankside soils, contents of recoverable $\mathrm{Hg}$ in the midstream bed sediment were higher ( 0.11 to $1.59 \mathrm{mg} / \mathrm{kg})$ than those in sediments from other streams in the watershed.

\section{Surface Water}

Of the major streams that are underlain by sediments of the CKKD and that drain to the Atlantic Ocean, the GEHR and its tributaries are the most extensively studied with respect to $\mathrm{Hg}$ levels (both $\mathrm{THg}$ and $\mathrm{MeHg}$ ). HAMM, a nearby stream, is a tributary to the Mullica River, another major Coastal Plain river (fig. 4). The upper reaches of the GEHR are surrounded by old and new urban land, whereas the lower reaches run mainly through forests and wetlands. The headwaters of HAMM are in old urban land that gives way to agricultural land farther downstream.
THg concentrations in unfiltered streamwater from the GEHR watershed, with the exception of streamwater in Squankum Branch, ranged from about 0.005 to $0.063 \mu \mathrm{g} / \mathrm{L}$ (Barringer and others, 2010a). For a variety of flow conditions, $\mathrm{Hg}$ concentrations tended to be higher in the more urbanized areas, and a greater proportion of the $\mathrm{Hg}$ was present on particles (unfiltered concentration minus filtered concentration) than in the forested wetlands areas. $\mathrm{THg}$ concentrations in unfiltered HAMM streamwater were generally lower $(0.002$ to $0.015 \mu \mathrm{g} / \mathrm{L}$ ) than those in most of the GEHR watershed (table 3B). In the course of this study, no measurements could be found for $\mathrm{Hg}$ evasion (a process where $\mathrm{Hg}$ is lost to the atmosphere) from New Jersey Coastal Plain streams, so the effect of this process on streamwater concentrations is not known.

$\mathrm{THg}$ concentrations in streamwater from Squankum Branch, in contrast to streamwater in the rest of the GEHR watershed that has been sampled during the past decade, have generally ranged from about $0.050 \mu \mathrm{g} / \mathrm{L}$ to $0.250 \mu \mathrm{g} / \mathrm{L}$; the latter concentration is substantially higher than the New Jersey Surface Water Quality Standard of $0.050 \mu \mathrm{g} / \mathrm{L}$. Squankum Branch flows next to a residential area where domestic well water has been found to be contaminated with $\mathrm{Hg}$ and is within an area that formerly contained fields with row crops and orchards. A recent study by Barringer and others (2010b) 


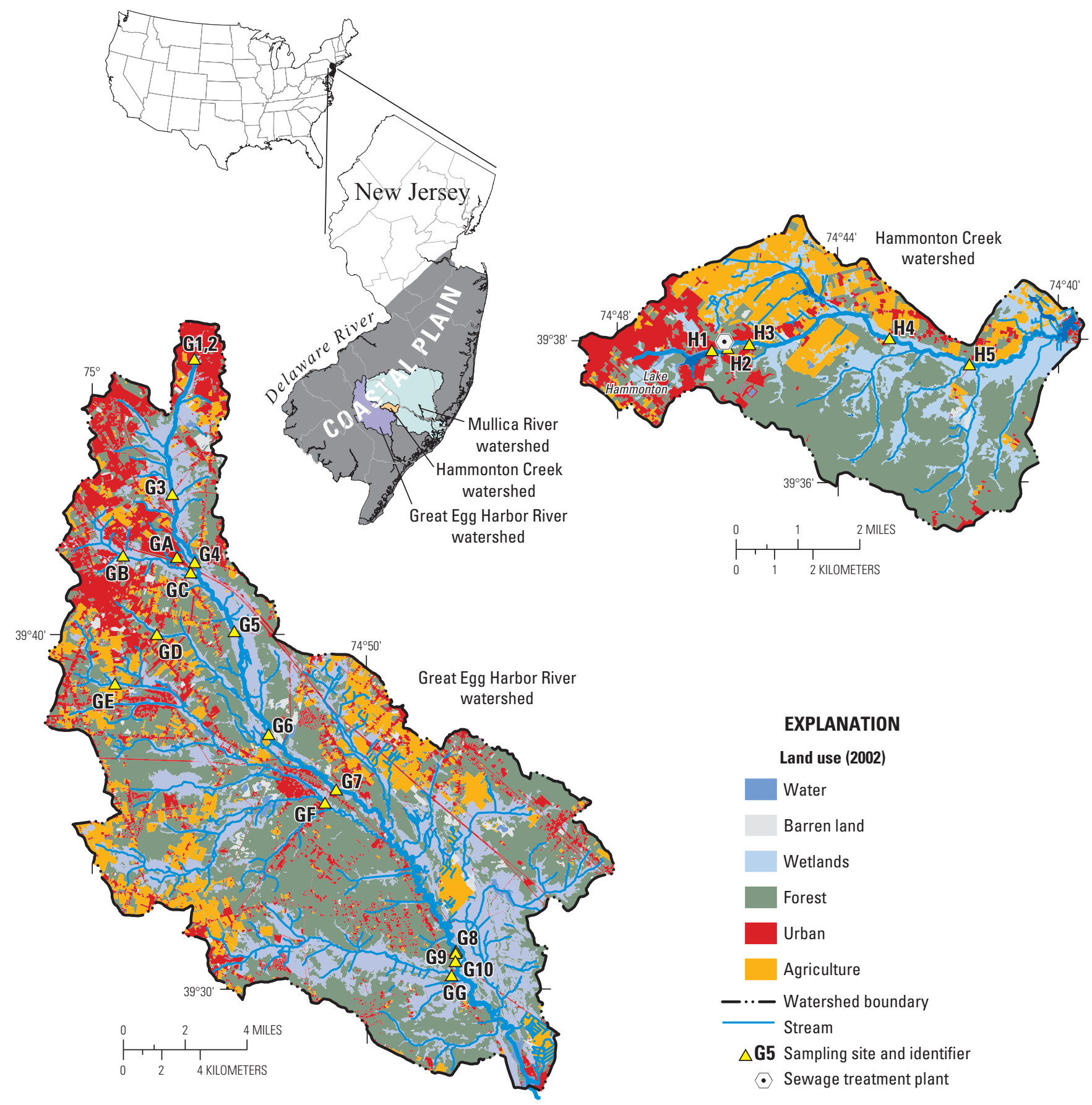

Figure 4. Land use (2002) within the non-tidal part of the Great Egg Harbor River watershed and Hammonton Creek watershed in New Jersey, with sampling sites from the U.S. Geological Survey 2006-08 investigations of mercury and methylmercury in the watersheds. 


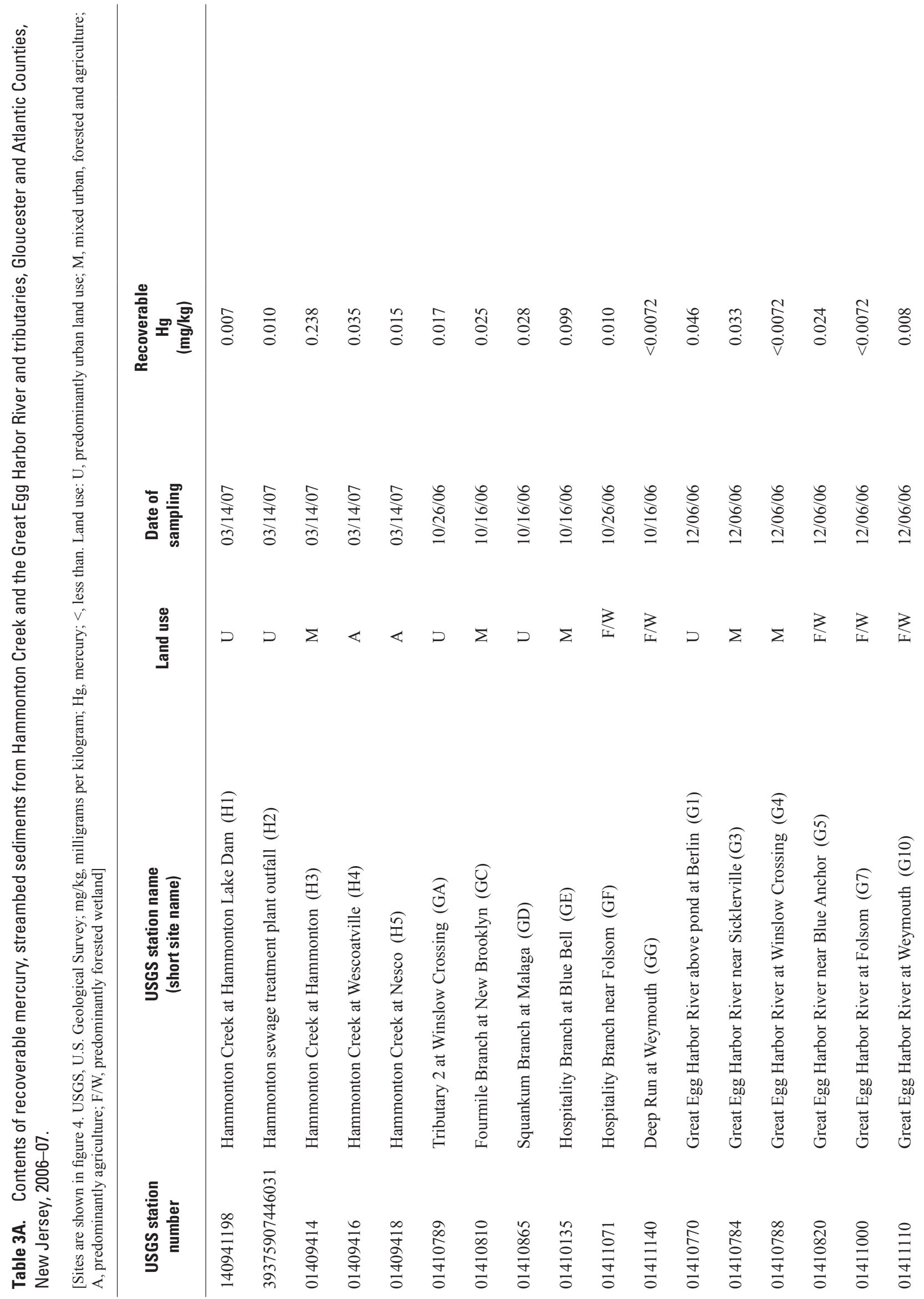




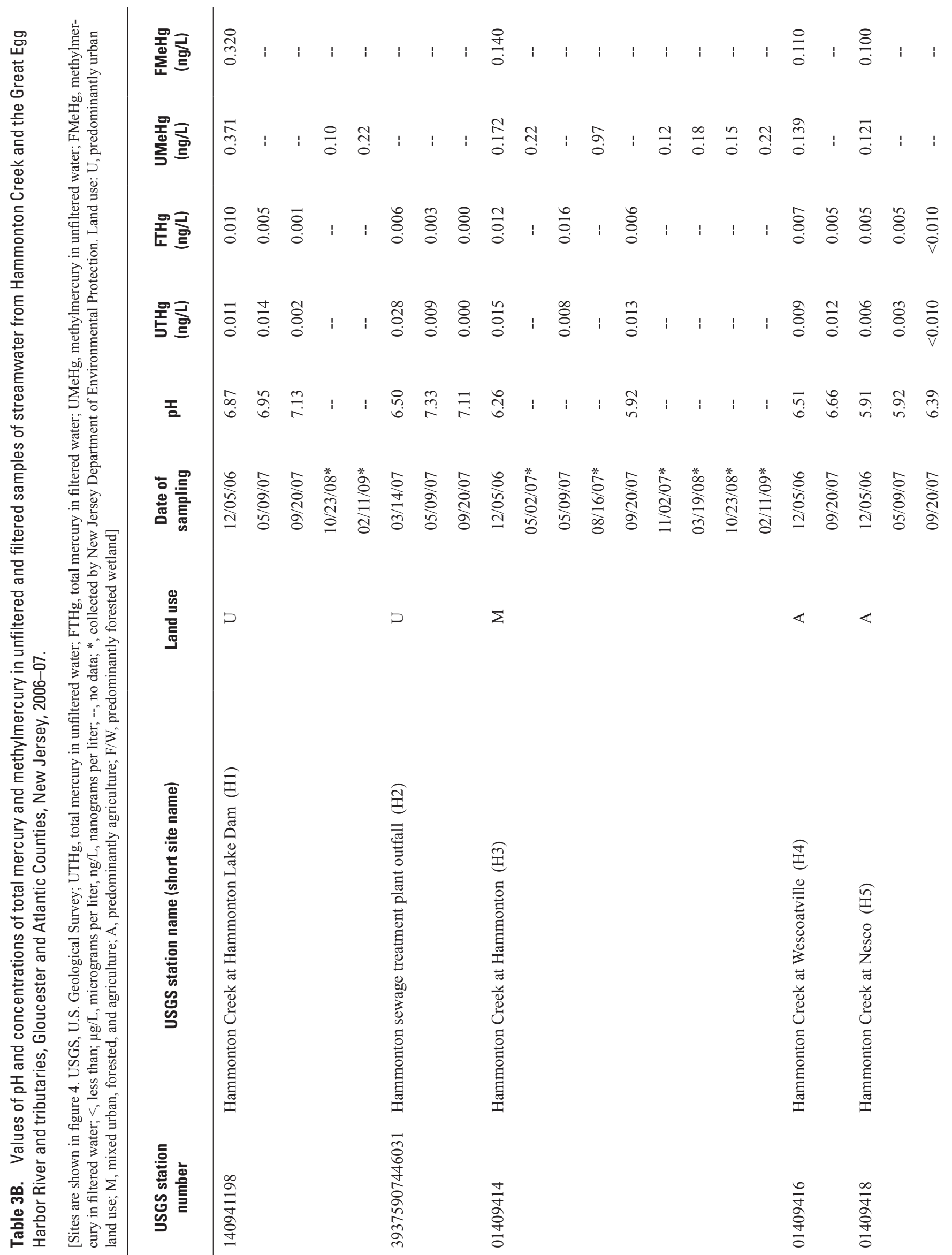




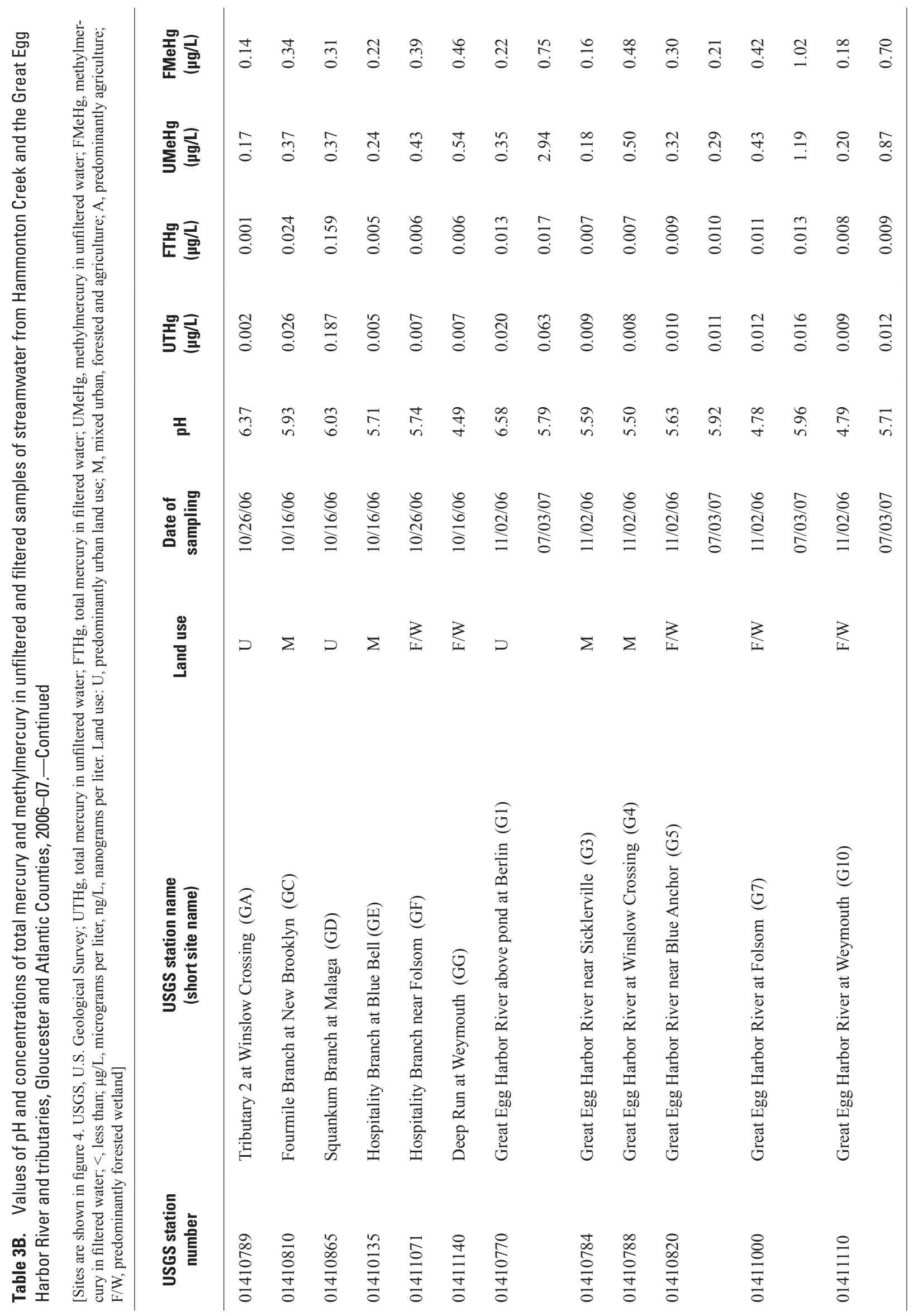


has shown that (unfiltered) shallow groundwater containing high concentrations of $\mathrm{THg}$ (1.80 to $5.65 \mu \mathrm{g} / \mathrm{L}$ ) discharges to Squankum Branch where it flows past the site with Hgcontaminated groundwater. It is plausible that, where other Coastal Plain streams flow past sites of Hg-contaminated groundwater, the streamwaters also receive $\mathrm{Hg}$-rich groundwater discharge; potential instances of local groundwater effects on surface-water quality, other than at Squankum Branch, have not been investigated to date (2012) by the NJDEP or the USGS.

Effects of mercury in the Coastal Plain acidic surfacewater bodies are seen in the biota. Fish-consumption advisories have been posted for most streams and lakes because fish tissues commonly have $\mathrm{MeHg}$ concentrations that exceed 1.0 milligram per kilogram $(\mathrm{mg} / \mathrm{kg}$ ) wet weight (Academy of Natural Sciences, 1994). A USGS nationwide study of 20 watersheds ranked the GEHR as one of the top six watersheds in the country with the highest concentrations of $\mathrm{MeHg}$ (wet weight) in fish and with $\mathrm{MeHg}$ and $\mathrm{THg}$ in streamwater (Brumbaugh and others, 2001).

\section{Possible Sources of Inorganic Mercury in the New Jersey Coastal Plain}

It was concluded early in the investigations of $\mathrm{Hg}$ in the New Jersey Coastal Plain that a natural (geologic) source of Hg was unlikely (Dooley, 1992); however, no chemical analyses of aquifer sediments were available, only mineralogical analyses. Given the former (mainly agricultural) and existing (residential) land use in the areas of contaminated groundwater, numerous anthropogenic sources were considered likely.

\section{Anthropogenic Sources}

Because of the common use of many Hg-bearing products and the abundance of $\mathrm{Hg}$ in coal used at power-generating stations, numerous anthropogenic sources can contribute $\mathrm{Hg}$ to the environment. In addition to emissions from power plants, some sources of $\mathrm{Hg}$ are emissions from other industrial plants, incinerators, and crematories and, as of 2012, agricultural chemicals (pesticides and fungicides). $\mathrm{Hg}$, as phenyl mercuric acetate, was used as a fungicide in house paint during the 1950s through 1980s, and was thereafter voluntarily removed by paint manufacturers. Mercury may still be present in some household chemicals such as bleach and drain cleaner as a result of its use as a catalyst at the chlor-alkali plants that produce these chemicals; the industry has attempted to reduce $\mathrm{Hg}$ in these materials (The Chlorine Institute, Inc., 2000), and the process is by now (2012) outmoded.

\section{Atmospheric Deposition}

Atmospheric deposition of $\mathrm{Hg}$ has been studied extensively since the 1970s; much of the $\mathrm{Hg}$ deposited from the atmosphere came from emissions from industry and coal-fired power plants (Glass and others, 1986; Lindberg, 1987; Nriagu and Pacyna, 1988; Glass and others, 1991; Slemr and Langer, 1992). In New Jersey, a NJDEP study found that background $\mathrm{Hg}$ concentrations in air ranged from 0.8 to 20 nanograms per cubic meter of air $\left(\mathrm{ng} / \mathrm{m}^{3}\right) ; \mathrm{Hg}$ in air near a municipal solid waste incinerator, with a median value of $2.5 \mathrm{ng} / \mathrm{m}^{3}$, was within global background levels (Greenberg and others, 1992). In the $1990 \mathrm{~s}, \mathrm{Hg}$ concentrations in precipitation ranged from 5 to 60 nanograms per liter (ng/L) with an apparent trend of decreasing concentrations with distance from highly urbanized areas (Barringer and others, 1997); these concentrations were measured during a time in which the 1990 Amendments to the Clean Air Act of 1970 (http://epa.gov/air/caa/caa_history. html-accessed 2/13/12) would have begun to take effect.

Studies have shown that the levels of $\mathrm{Hg}$ in soils and surface waters tend to increase with the percentage of land cover that is wetlands. This increase occurs because atmospherically deposited $\mathrm{Hg}$ has been sequestered by organic matter in wetlands soils and is transported in porewaters and surface waters with organic carbon (Mierle and Ingram, 1991; Krabbenhoft and others, 1995; Hurley and others, 1995; Kolka and others, 1999; Wu and others, 2004). In the Atlantic Coastal Plain, the extensive wetlands areas can act as sinks for atmospherically deposited $\mathrm{Hg}$. The levels of $\mathrm{THg}$ in various media of the Coastal Plain of South Carolina tend to be higher than those in upland areas of the Piedmont Physiographic Province, which are farther inland (Guentzel, 2009). In the New Jersey Coastal Plain (GEHR watershed), an increase in the percentage of the $\mathrm{THg}$ as $\mathrm{MeHg}$ was associated with an increase in the percentage of wetlands (Barringer and others, 2010a).

Although there is retention of atmospherically deposited THg in wetlands soils in the New Jersey outer Coastal Plain, the $\mathrm{Hg}$ concentrations in groundwater underlying developed areas clearly exceed the background concentrations (less than $0.01 \mu \mathrm{g} / \mathrm{L}$ ) in undeveloped areas (Barringer and Szabo, 2006). Therefore, sources other than just atmospheric THg need to be sought in the residentially developed areas. Obvious point sources, such as landfills, industrial operations, military installations, cemeteries, and golf courses, have been investigated as potential sources of the $\mathrm{THg}$ that contaminates the groundwater (Barringer and others, 1997). These potential sources have not, in most cases, been conclusively linked to the residential areas where the $\mathrm{THg}$-contaminated groundwater is found (Barringer and others, 1997). Although the point sources listed above have yet to be identified as important sources of the widespread domestic well-water contamination by $\mathrm{Hg}$, groundwater at or near various landfills (not associated with the residential areas) has, in some cases, been affected (Barringer and others, 1997). 


\section{Agricultural Chemicals}

Given that many of the residential areas where THg-contaminated groundwater has been found are on former agricultural land, the possibility of mercurial pesticide applications as a source was explored (Barringer and others, 1997). THg-contaminated domestic-well water was first observed in 1982, and discoveries of THg in well water has continued throughout the 1980s to the present (2012). The age of the water reaching domestic wells that ranged in depth from about 50 to $120 \mathrm{ft}$ was estimated in 1997 on the basis of model simulations to be about 10 to 35 years (Barringer and others, 1997); more recent age dating and groundwater modeling (Modica and others, 1998; Barringer and MacLeod, 2001; Kauffman and others, 2001; Cauller and Carleton, 2006) indicate that these ages are young by a few years at most. The housing developments generally were completed in the late 1970s; at that time and later, the aggregate of pumping domestic wells likely would have altered flow paths and groundwater velocities. The appearance of the THg in domestic-well water less than 10 years after the developments were completed indicates that the THg was most likely already present in the soils and, perhaps, already leaching to groundwater. The leaching process probably was being accelerated by the disturbance of soils during the residential development. Thus former mercurial pesticide applications appeared to be a viable source of $\mathrm{THg}$ to groundwater.

Mercuric chloride $\left(\mathrm{HgCl}_{2}\right)$ at $7.4 \times 10^{7} \mu \mathrm{g} / \mathrm{L}$ is highly soluble in water (Merck, 1983). $\mathrm{HgCl}_{2}$ was commonly used as an agricultural pesticide during the mid-20th century; recommended application rates were as great as $1 \times 10^{9} \mathrm{mg}$ per acre per year (Murphy and Aucott, 1999; Barringer and others, 1997 and references therein). Pesticides containing $\mathrm{Hg}$ were recommended for use on lawns for crabgrass control during the mid 20th century (Wolf and Engel, 1948). Also, pesticides with $\mathrm{Hg}$ were used on row crops during the same time period (Murphy and Aucott, 1999). Therefore, soils in agricultural areas later to become residential areas could well have received THg from both types of application. Additionally, fertilizers could contribute $\mathrm{Hg}$ to soils; analysis of a commercial 20-20-20 fertilizer solution (mixed according to manufacturer's directions) identified $282 \mu \mathrm{g} / \mathrm{L}$ of $\mathrm{Hg}$ in the solution (Barringer and MacLeod, 2001).

Although soils may have received substantial amounts of THg through pesticide applications, leaching of soluble $\mathrm{HgCl}_{2}$ over time, particularly during soil disturbance, may have substantially reduced any residual evidence of these applications to soils. Leaching experiments indicate that $\mathrm{Hg}$ can be readily removed from the sandy sediments (from the Bridgeton and Cohansey Formations) by water, road-salt solutions, and fertilizer solutions (Barringer and MacLeod, 2001). Volatilization at the soil surface also may have removed $\mathrm{Hg}$, although experiments have shown that volatilization of $\mathrm{HgCl}_{2}$ from sandy soils resulted in relatively small losses to the atmosphere (Poelstra and others, 1974; Hogg and others, 1978). In any case, little if any trace of pesticide $\mathrm{Hg}$ has been observed in residential soils examined as part of USGS studies as of 2005 to 2006.
As discussed above, results of analyses indicate that the $\mathrm{THg}$ concentrations in soil samples from residential developments (typically less than $0.050 \mathrm{mg} / \mathrm{kg}$ ) were substantially less than the THg concentrations in soils from undisturbed forested areas (about $0.10-0.15 \mathrm{mg} / \mathrm{kg}$ ), where inputs of $\mathrm{THg}$ would be from geologic sources and atmospheric deposition only (Barringer and others, 1997; Barringer and Szabo, 2006). The disparity between $\mathrm{Hg}$ contents of undisturbed and disturbed soils (where the Hg content in undisturbed soils is higher than that of disturbed soils) is attributed to mobilization of $\mathrm{Hg}$ during disturbance created by a change in land use (Barringer and Szabo, 2006). The assumption here is that $\mathrm{Hg}$ originally present in the agricultural soils was lost to evasion and to leaching and transport on particles to the water table when the soils were disturbed (horizons overturned and mixed) during residential development.

A recent (2008-09) investigation by the USGS and the NJDEP at Squankum Branch in a former agricultural area of Gloucester County, New Jersey, found that high concentrations of THg are present in bankside soils. As mentioned above, samples of soil and sediment from the banks of Squankum Branch, a small headwaters stream (fig. 3; table 2) contained as much as $12.2 \mathrm{mg} / \mathrm{kg}$ of recoverable (HCl-leachable) $\mathrm{Hg}$ - a content about two orders of magnitude greater than the content of undisturbed forested soils reported by Barringer and others (1997). The Squankum Branch soils with the high Hg contents were rich in organic carbon, but organic-rich soils in the area did not universally contain such high $\mathrm{Hg}$ contents. Moreover, elevated contents of arsenic $(\mathrm{As})$ and lead $(\mathrm{Pb})$ in some of the soil samples from Squankum Branch watershed (table 2) indicate that the organic soils may have retained agricultural pesticide residues, such as lead arsenate that was used on orchards (Barringer and others, 1998, Murphy and Aucott, 1998), or trapped residues transported in runoff to the stream. Further, shallow groundwater entering the stream from the banks contained THg in concentrations as great as $5 \mu \mathrm{g} / \mathrm{L}$ (Barringer and others, 2010b), a concentration that substantially exceeds the New Jersey MCL. Additionally, shallow groundwater also contained greater than background concentrations of nitrate $\left(\mathrm{NO}_{3}^{-}\right)$, which may have derived from the former use of fertilizers or from septic tanks, which are common in rural agricultural areas. These findings are the first evidence that shallow groundwater can contain high concentrations of $\mathrm{THg}$ in a former agricultural area.

\section{Household Sources}

Attempts to identify anthropogenic inputs of $\mathrm{Hg}$ in deep groundwater ( $>60 \mathrm{ft}$ below land surface) have been complicated by the presence of $\mathrm{NO}_{3}{ }_{3}$ and chloride $\left(\mathrm{Cl}^{-}\right)$, which are common to both agricultural fertilizers and septic-system effluents. In several unsewered residential areas, elevated concentrations of $\mathrm{NO}_{3}^{-}$, some exceeding the New Jersey MCL of $10 \mathrm{mg} / \mathrm{L}$ as nitrogen $(\mathrm{N})$, were present in domestic well water (data in Barringer and MacLeod, 2001). For some of these wells, strong positive relations between $\mathrm{NO}_{3}{ }^{-}$and magnesium 
$(\mathrm{Mg})$ and barium $(\mathrm{Ba})$ appear indicative of agricultural inputs of lime (dolomite) and fertilizer, as indicated in the study by Kozinski and others (1995). Domestic well waters also contained concentrations of $\mathrm{Cl}^{-}$that were much greater than background levels of 3 to $5 \mathrm{mg} / \mathrm{L}$ (Yuretich and others, 1981; Kozinski and others, 1995; Barringer and others, 2006); in one study of a residential area (the CSL site; fig. 1) near Squankum Branch, methylene blue active substances (MBAS), which include surfactants, were found in well water (Barringer and others, 2006), indicating likely inputs to shallow groundwater from the septic systems.

A household septic system in the 1980s and 1990s could have received $\mathrm{Hg}$ present as a contaminant in bleach and in sodium hydroxide $(\mathrm{NaOH})$ used as drain cleaner. Calculations for bleach use show that other household water use (presumed to not contain $\mathrm{Hg}$ ) would be sufficient to dilute such $\mathrm{Hg}$ to negligible concentrations (Barringer and others, 1997), and the same can be shown to be true for $\mathrm{NaOH}$, which would be used far less often than bleach. On the basis of limited analyses of leach-field-effluent samples collected by the USGS (Barringer and others, 2006), septic-system effluent in the leach fields sampled did not contribute extensive amounts of $\mathrm{Hg}$ to subsoils. Low effluent inputs of Hg support the earlier calculations of likely septic-system inputs of $\mathrm{Hg}$ from household chemicals (Barringer and others, 1997). Septic-system effluent primarily appears to create a geochemical environment in which $\mathrm{Hg}$ is mobilized, rather than representing a major source of $\mathrm{Hg}$ in the New Jersey Coastal Plain (Barringer and Szabo, 2006). Nevertheless, samples of backwash brines (table 4) were collected from several common household water-treatment systems; these were water-softening cation-exchange units or $\mathrm{pH}$-adjustment units, not the Hg-removal point-ofentry-treatment systems supplied by NJDEP to households. These samples were collected in 2008 at a site in Burlington

Table 4. Concentrations of selected constituents and values of $\mathrm{pH}$ in backwash brines from household water-treatment systems at three domestic wells in Burlington County, New Jersey, 2008-09.

[USGS, U.S. Geological Survey; $\mu \mathrm{g} / \mathrm{L}$, micrograms per liter; $\mathrm{mg} / \mathrm{L}$, milligrams per liter; THg, total mercury; DO, dissolved oxygen; $\mathrm{Cl}-$, chloride; na, not analyzed]

\begin{tabular}{lccccc}
\hline $\begin{array}{c}\text { Type of well/ } \\
\text { USGS well } \\
\text { number }\end{array}$ & $\begin{array}{c}\text { THg, } \\
\text { unfiltered } \\
(\boldsymbol{\mu g} / \mathbf{L})\end{array}$ & $\begin{array}{c}\text { THg, } \\
\text { filtered } \\
(\boldsymbol{\mu g} / \mathbf{L})\end{array}$ & $\begin{array}{c}\text { DO } \\
(\mathbf{m g} / \mathbf{L})\end{array}$ & $\begin{array}{c}\mathbf{p H} \\
\text { (units) }\end{array}$ & $\begin{array}{c}\mathbf{C l}- \\
(\mathbf{m g} / \mathbf{L})\end{array}$ \\
\hline $\begin{array}{c}\text { Domestic/well } \\
051764\end{array}$ & 6.9 & na & 5.09 & 6.44 & 5,300 \\
$\begin{array}{c}\text { Domestic/well } \\
051766\end{array}$ & 9.4 & 0.260 & 11.8 & 5.89 & 9.13 \\
$\begin{array}{c}\text { Domestic/well } \\
051789\end{array}$ & 5.4 & 0.091 & na & & \\
\hline
\end{tabular}

County with $\mathrm{Hg}$-contaminated well water. The brines contained as much as $9 \mu \mathrm{g} / \mathrm{L}$ of THg. (Most homeowners use tanks filled with limestone chips for $\mathrm{pH}$ neutralization; these typically use $\mathrm{NaCl}$ for backwashing the units.) In the case of utility treatment systems, where the unit may use $\mathrm{NaOH}$ as a neutralizer, this chemical could have been contaminated with $\mathrm{Hg}$ if it was initially produced in a chlor-alkali plant (where $\mathrm{Hg}$ is used in the production process). Voluntary efforts on the part of the chlorine industry (The Chlorine Institute, Inc., 2000) have presumably lowered the amount of $\mathrm{Hg}$ in $\mathrm{NaOH}$, and the chlor-alkali process that used $\mathrm{Hg}$ is very nearly phased out; thus any $\mathrm{Hg}$ in $\mathrm{NaOH}$ used in a utility treatment unit has presumably declined over time. However, for the recent samples of household backwash brines reported in table 4, the THg is predominantly contributed by the contaminated groundwater that has passed into the system because domestichousehold treatment systems do not use $\mathrm{NaOH}$. The backwash $\mathrm{THg}$ is routinely cycled back to subsoils along with other components of the backwash brine such as $\mathrm{Cl}^{-}$. The backwash is released in some cases to septic systems and, in others, through dry wells to the subsoils. As evidenced by high $\mathrm{Cl}^{-}$ concentrations in groundwater in residential areas and further studies of brine wastes (Szabo and others, 2008; Szabo and others, 2010a), such backwash solutions can reach the water table and move farther into the aquifer.

Pesticide application appears to be a likely anthropogenic source of THg in CKKD water because most wells contaminated by THg were installed on former agricultural land (Barringer and others, 1997). The findings at Squankum Branch help to support this contention. In the latter part of the 20th century, household inputs of THg-bearing substances, such as bleaches and paints, appear to have been a minor source (Barringer and others, 1997), although the recent backwash-brine data do indicate an additional and perhaps more substantial household source.

\section{Other Anthropogenic Sources}

During the Hg investigations by USGS and NJDEP in the 1990s, it was noted that many of the residential areas with Hgcontaminated well water were distributed along defunct railroad rights-of-way. Use of $\mathrm{Hg}$-rich coal in steam engines may have affected atmospheric $\mathrm{THg}$, but no data on other railroad uses of $\mathrm{Hg}$ were available at the time (Barringer and others, 1997). A study in France, however, (Bollen and others, 2008) showed that groundwater was contaminated with $\mathrm{Hg}$ at a site where wood was preserved (kyanized) with the highly soluble $\mathrm{HgCl}_{2}$. Railroad ties once presented a major use of such wood, and it may be that kyanized wood was used in the New Jersey railroads. If so, such use may represent another anthropogenic source of $\mathrm{Hg}$ to Coastal Plain soils and waters. As yet, this possibility has not been explored.

The possibility that leachate from landfills affected groundwater was considered, but it appears that groundwater in landfill areas does not flow toward the nearby residential areas studied in the 1980s and 1990s (Barringer and others, 
1997). Landfills do emit $\mathrm{Hg}$ in gases that vent to the atmosphere (Kim and Kim, 2002; Feng and others, 2004; de la Rosa and others, 2006). Thus, in parts of southern New Jersey, atmospheric deposition may contain some $\mathrm{Hg}$ acquired locally from landfill emissions.

\section{Natural Sources}

An early investigation by Dooley (1992) concluded that the mineralogy of CKKD sediments precluded a viable geologic source of THg, so the aquifer sediments were unlikely to supply $\mathrm{Hg}$ to the groundwater. At the time of Dooley's study (1992), no data on the $\mathrm{Hg}$ contents of aquifer sediments, particularly clay, were available. As of 2012, several studies have shown that organic-rich clays that are present in lenses throughout the aquifer system can contain substantial contents of $\mathrm{Hg}$ (Barringer and others, 1997; table 1). Data obtained since 1992 (discussed below) indicate that, in the absence of evidence of anthropogenic inputs of $\mathrm{Hg}$ to the CKKD sediments, a natural source cannot be completely ruled out.

Concentrations of $\mathrm{Hg}$ in groundwater in undeveloped areas, as of 2012, have been found to be low (less than $0.01 \mu \mathrm{g} / \mathrm{L}$ ), indicating that under conditions that are not affected by human activities, Hg in aquifer sediments (particularly clays) is not extensively released to groundwater. To test whether proximity to clay lenses could affect $\mathrm{Hg}$ concentrations in groundwater, clusters of observation wells were screened above and below clay lenses (Barringer and others, 2005). Results of analyses of water from these wells did not, in most cases, indicate higher $\mathrm{Hg}$ concentrations in water samples collected near the clay lenses (Barringer and others, 2005). Lenses of kaolinitic light-colored clays abound throughout the CKKD and likely contain little $\mathrm{Hg}$ because they contain little organic matter. For the dark, organic-rich clays in which $\mathrm{Hg}$ contents are relatively high (as much as $0.13 \mathrm{mg} / \mathrm{kg}$ based on data in table 1 ), the mechanism by which the $\mathrm{Hg}$ is released to groundwater has yet to be determined. Previously conducted studies (Barringer and others 1997;
Barringer and Macleod, 2001; Barringer and others, 2005; Barringer and others, 2006; Barringer and Szabo, 2006) indicate that where concentrations of $\mathrm{Hg}$ are elevated (greater than background levels) or at contaminant levels ( $2 \mu \mathrm{g} / \mathrm{L}$ or greater), anthropogenic sources of $\mathrm{Hg}$ are likely to be present and that mobilization of $\mathrm{Hg}$ by anthropogenic chemicals from soils to groundwater, as of 2012, appears to be the major mechanism by which groundwater becomes contaminated with $\mathrm{Hg}$ (Barringer and Szabo, 2006).

None of the studies has shown conclusively that high levels of $\mathrm{Hg}$ are released from aquifer materials; however, there are no data that conclusively rule out this possibility. Although the sediments that compose the CKKD do not contain common $\mathrm{Hg}$-bearing minerals such as sulfides, the limited chemical analyses of CKKD sediments indicate that the $\mathrm{Hg}$ contents of gray to black, organic-rich clays, which range from 0.060 to $0.13 \mathrm{mg} / \mathrm{kg}$ (table 1), are substantially greater than the contents of sand samples (less than $0.010 \mathrm{mg} / \mathrm{kg}$ ). The higher $\mathrm{Hg}$ content of clay relative to that of sand also was reported in Barringer and others (1997).

Although a mechanism for release of $\mathrm{Hg}$ from aquifer sediments (clays) has not been determined, recent sampling indicates that $\mathrm{Hg}$ might be released from geologic materials. A domestic well at a relatively isolated house amid cranberry bogs was sampled in 1998 during a time when the house was occupied and the well was pumped on a regular basis. The well (number SUSCP30, fig. 1) was completed at $101 \mathrm{ft}$ below land surface in the CKKD below four clay layers. At that time, the THg concentration in filtered well water was $0.56 \mu \mathrm{g} / \mathrm{L}$, substantially greater than background levels but not considered to be at contaminant levels (that is, in excess of $2 \mu \mathrm{g} / \mathrm{L}$ ). In 2006, the well was resampled after the house had been unoccupied for several months. Multiple water samples were collected during the well purging; all contained concentrations of $\mathrm{THg}$ substantially greater than the MCL, ranging from about 9.7 to $11 \mu \mathrm{g} / \mathrm{L}$ (Szabo and others, 2010b). Other constituents showed virtually no change from 1998 levels (table 5). The only substantial chemical difference was in the

Table 5. Field properties, concentrations of total mercury, and dissolved major and trace constituents in well water from domestic well SUSCP30 in cranberry bog area in New Jersey, 1998 and 2006.

[Values are for filtered water, except for field properties (T, SC, DO, pH), which were measured in unfiltered water. T, temperature; ${ }^{\circ} \mathrm{C}$, degrees Celsius; $\mathrm{SC}$, specific conductance; $\mu \mathrm{S} / \mathrm{cm}$ at $25^{\circ} \mathrm{C}$, microsiemens per centimeter at 25 degrees Celsius; DO, dissolved oxygen; mg/L, milligrams per liter; Ca ${ }^{2+}$, calcium, $\mathrm{Mg}^{2+}$, magnesium; $\mathrm{Na}^{+}$, sodium, $\mathrm{K}^{+}$, potassium, $\mathrm{Cl}^{-}$, chloride; $\mathrm{SO}_{4}{ }^{2-}$, sulfate; $\mathrm{NO}_{2}{ }^{-}+\mathrm{NO}_{3}{ }^{-}$, nitrite + nitrate; $\mathrm{NH}_{4}^{+}$, ammonium; $\mathrm{THg}$, total mercury; Fe, iron; $\mathrm{Mn}$, manganese; $\mu \mathrm{g} / \mathrm{L}$, micrograms per liter]

\begin{tabular}{|c|c|c|c|c|c|c|c|c|c|c|c|c|c|c|c|}
\hline Date & $\begin{array}{c}\mathrm{T} \\
\left({ }^{\circ} \mathrm{C}\right)\end{array}$ & $\begin{array}{c}S C \\
(\mu S / c m \\
\left.\text { at } 25^{\circ} \mathrm{C}\right)\end{array}$ & $\begin{array}{c}\text { DO } \\
\text { (mg/L) }\end{array}$ & pH & $\begin{array}{c}\mathrm{Ca}^{2+} \\
\text { (mg/L) }\end{array}$ & $\begin{array}{c}\mathrm{Mg}^{2+} \\
(\mathrm{mg} / \mathrm{L})\end{array}$ & $\begin{array}{c}\mathrm{Na}^{+} \\
\text {(mg/L) }\end{array}$ & $\begin{array}{c}\mathrm{K}^{+} \\
\text {(mg/L) }\end{array}$ & $\begin{array}{c}\mathrm{Cl}^{-} \\
\text {(mg/L) }\end{array}$ & $\begin{array}{c}\mathrm{SO}_{4}^{2-} \\
(\mathrm{mg} / \mathrm{L})\end{array}$ & $\begin{array}{l}\mathrm{NO}_{2}^{-} \\
+\mathrm{NO}_{3}^{-} \\
\text {(mg/L } \\
\text { as N) }\end{array}$ & $\begin{array}{l}\mathrm{NH}_{4}^{+} \\
(\mathrm{mg} / \mathrm{L} \\
\text { as } \mathrm{N})\end{array}$ & $\begin{array}{c}\mathrm{THg} \\
(\mu \mathrm{g} / \mathrm{L})\end{array}$ & $\begin{array}{c}\mathrm{Fe} \\
(\mu \mathrm{g} / \mathrm{L})\end{array}$ & $\underset{(\mu \mathrm{g} / \mathrm{L})}{\mathrm{Mn}}$ \\
\hline 1998 & 13.60 & 53.0 & 1.34 & 4.13 & 1.00 & 1.00 & 5.70 & 0.60 & 13.0 & 0.40 & 0.080 & 0.050 & 0.56 & 10.0 & 11.0 \\
\hline
\end{tabular}


dissolved oxygen (DO) concentration, which had declined from 1.34 to $0.52 \mathrm{mg} / \mathrm{L}$. In both samplings, anthropogenic chemicals, such as pesticides and volatile organic compounds (VOCs), were not detected in the well water, and no clear effects of anthropogenic activities on the water chemistry were apparent. The clay lenses reported in the log for this domestic well are probably laterally extensive because cranberry bogs are developed only in areas where drainage is restricted by clays beneath the land surface because flooding of the bogs is needed for harvest. Therefore, it is unlikely that any surficial applications of anthropogenic chemicals would have been transported to depth at this site, and there is no evidence from the groundwater chemistry that this has occurred. It appears that water withdrawals had, in 1998, moved water with relatively low $(1.34 \mathrm{mg} / \mathrm{L})$ but measureable concentrations of oxygen to the well. After the water withdrawals ended, less oxygenated water flowed toward the well screen; without the pumping, water would have been under ambient flow conditions, and flowpaths probably would have been more local than when the well was being pumped. This change in flow conditions apparently caused a shift to more reducing conditions in the volume of aquifer surrounding the well, in turn, leading to a substantial increase in the $\mathrm{THg}$ concentration in the water locally. In the absence of an obvious anthropogenic source, the source of the THg could be geologic in nature. The clays are described as "yellow" and "white" in the driller's log and, thus, are probably low in organic matter, but organic-rich materials could be present that were not recorded in the driller's log. Indeed, the increasingly reducing conditions when pumping ceased indicates the likelihood that, at depth, organic material is being microbially degraded. Clearly a source of $\mathrm{Hg}$ is present at depth (possibly lignite, which is present locally in the deeper aquifer sediments (Eric Jacobsen, U.S. Geological Survey, oral commun., 2010)) that appears to be near the well. There is no evidence for an anthropogenic source of $\mathrm{Hg}$. The data that exist for the entire region, as of 2012, indicate that THg is partitioned selectively into aquifer materials, such as the organic-rich clays. Lignite fragments could be enriched in $\mathrm{Hg}$, as lignites are known to contain $\mathrm{Hg}$ concentrations that range from less than $0.006 \mathrm{mg} / \mathrm{kg}$ to $15 \mathrm{mg} / \mathrm{kg}$ (Yudovich and Ketris, 2008); as of 2012, no analyses are available for lignite from the CKKD. Such Hg-enriched materials (clays and, possibly, lignites) are distributed unevenly throughout the aquifer, occurring wherever low energy environments, such as lagoons and swamps, existed in the near-shore and deltaic Miocene Epoch landscape in which the CKKD sediments were deposited.

\section{Factors Affecting Mobility}

Several major factors affect how THg is mobilized in soils, within the aquifer, and in streamwater. Determining whether the Hg is mainly particulate or dissolved is important; if $\mathrm{Hg}$ is dissolved, then a determination of its chemical form (ionic or elemental) can be used to predict its chemical behavior through the soil column or along groundwater flowpaths. Because streams in the Coastal Plain during base flow receive most of their water from groundwater discharge, mobile mercury in groundwater could be delivered to streams where chemical reactions can change the form of mercury and, thus, its partitioning behavior and mobility. Other important factors affecting mercury mobility are the chemical constituents that accompany the THg.

\section{Mercury Forms}

As of 2012, studies conducted by the USGS and NJDEP have not included sampling to determine whether some of the THg present in Coastal Plain streamwaters and groundwater is in dissolved form or whether the THg that passes $0.45-\mathrm{mm}$ filters is largely colloidal. Studies (Ryan and Gschwend, 1994; Szabo and others, 2002) have shown that colloids are present in CKKD groundwater, and it has been hypothesized that some THg is transported within the aquifer on colloids (Barringer and Szabo, 2006). (Recent sampling (2009-10) at the William J. Hughes Technical Center (WJHTC) indicates that THg-bearing colloids are present, as discussed below.) There is ample evidence that some well-water samples contain THg on particles larger than $0.45 \mathrm{~mm}$. The presence of particulate THg in domestic well water was first found in samples collected by NJDEP in 1991; roughly one-third to one-half of the THg apparently was particulate (unfiltered $\mathrm{THg}$ - filtered $\mathrm{THg}$ = particulate THg; Barringer and others, 1997; Barringer and MacLeod, 2001). Particulate THg also was found in groundwater samples collected by the USGS (Barringer and Szabo, 2006), though this form was rarely predominant. During recent (2012) sampling at the Burlington County site (fig. 1) several domestic wells (051789, 051765, and 051766) produced water with greater than background or contaminant levels of THg. The first-draw samples from the domestic wells tended to contain particulate THg, and concentrations of THg tended to decline in subsequent samples collected during purging (Szabo and others, 2010b). The data do not clearly indicate whether changes in DO concentrations during purging affected the concentrations of particulate Hg. Ryan and Gschwend (1994) showed that greater concentrations of colloids were present under reducing conditions, but in the USGS study, the DO concentrations measured in first-draw and subsequent samples from the domestic wells differed only slightly and did not indicate changes from anoxic or suboxic conditions to oxic conditions as pumping proceeded. Samples were collected from these wells at household taps throughout the day, without purging, to simulate householder use. Particulate THg was present in the samples (fig. 5; table 6), but the percentage of particulate $\mathrm{THg}$ was different at each well. In addition, samples of shallow groundwater discharging to Coastal Plain streams also were found to contain particulate $\mathrm{THg}$; the particulate form was especially prevalent in urban areas (Barringer and others, 2010a), which probably indicates 


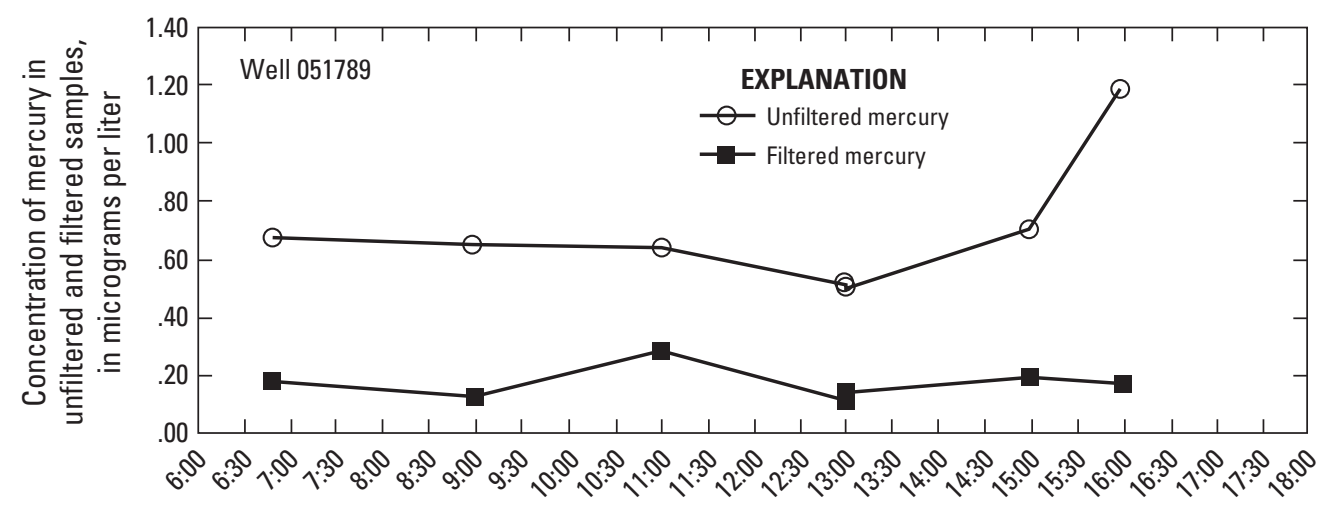

Time of sampling

Figure 5. Concentrations of total mercury in unfiltered and filtered water collected throughout the day from domestic well 051789 completed in the Kirkwood-Cohansey aquifer system, Burlington County, New Jersey, June, 2009. (Particulate mercury is the difference between unfiltered and filtered concentrations.)

the presence of reducing conditions in the aquifer in urban areas. Such reducing conditions, which appear to be randomly distributed spatially, have been shown to be associated with plumes of septic-system effluent in some instances (Barringer and others, 2006).

In a cooperative study with NJDEP during 2010-11, leaching experiments were performed by the USGS on subsoils (B horizon or zone of accumulation) from a forested area near the Burlington County residential site (fig. 1) where Hg-contaminated groundwater was present. The B-horizon soils, which were orange and rich in Fe hydroxides, contained $0.01 \mathrm{mg} / \mathrm{kg}$ of THg. These soils were composited from several cores, mixed well, and loaded into columns that were irrigated from the column base (to avoid gravity-affected collection of particles at the bottom screen) with 4 liters of solution at a rate of 5.9 to 6.5 milliliters per minute, simulating conditions of rapid recharge following a storm. Three leaching solutions consisted of a 0.1 molar $\mathrm{NaCl}$ solution to simulate roadsalt leaching, a 20-20-20 fertilizer solution, and de-ionized water (Reilly and others, 2012). In all cases, the THg that was removed by the leaching solutions was particulate $\mathrm{THg}$ at concentrations of about 0.28 to $0.45 \mu \mathrm{g} / \mathrm{L}$ (table 7). A substantial amount of particulate $\mathrm{Fe}$ also was removed in the leachate from the $\mathrm{NaCl}$ and de-ionized water experiments, probably indicating that the $\mathrm{THg}$ removed was sorbed to Fe hydroxide particles. In the fertilizer experiments, the 20-20-20 fertilizer solution contained a substantial concentration of $\mathrm{Fe}$, some of which was particulate. The Fe removed in the leachate also was predominantly particulate; these particles may have been the dominant vehicle for $\mathrm{THg}$ removal from soil to water table as indicated by Barringer and Szabo (2006). Illuviated layers of clays and hydroxides form naturally at the water table of the CKKD in undeveloped areas (Richard Walker, U.S. Geological Survey, oral commun., 2010) so it is reasonable to expect that Hg-rich particles in soils will be leachable and mobile, particularly when the soils are disturbed.
As yet, it is not known conclusively whether THg on particulates persists in that form once the water table is reached. Under certain circumstances (reducing conditions), it appears that $\mathrm{Fe}$ hydroxides in subsoils and aquifer sediments are reductively dissolved, and associated (presumably sorbed) THg is released (fig. 6; Barringer and MacLeod, 2001; Barringer and others, 2006). Under sulfate-reducing conditions, the released THg also may be reduced to elemental $\mathrm{Hg}\left(\mathrm{Hg}^{0}\right)$ by magnetite (Wiatrowski and others, 2009), which may be formed along with sulfides during microbial activity (Burton and others, 2011). Whether the Hg remains in dissolved form as $\mathrm{Hg}^{0}$ or whether it is re-oxidized and becomes re-associated with particles is not known, but the presence of THg-bearing particulate material in some well-water samples indicates this association does occur (Barringer and Szabo, 2006). Most of the well-water samples collected by county agencies and NJDEP were unfiltered; a few filtered samples were collected. Nevertheless, sufficient data have accumulated over the last two decades to verify that some of the mobile THg in groundwater is in particulate form.

The nature of the particles with which THg is associated in groundwater is not, as yet, clear. Water collected from a septic-system effluent plume (Barringer and others, 2006) contained aqueous sulfide, and results of geochemical speciation modeling, using the PHREEQC program (Parkhurst and Appelo, 1999), indicated that Hg-sulfide (metacinnabar) could precipitate. Mercury-bearing sulfides likely do not persist in oxygenated water. Consequently, THg in sulfide form may be present locally where conditions are reducing, such as in organic-rich wetlands or in substantive organic wastewater plumes, but is unlikely to be present throughout most parts of the typically oxygenated aquifer. There is evidence that $\mathrm{THg}$ can be associated with Fe hydroxides (discussed in greater detail farther on in the report), but as yet, there is no clear evidence that THg is associated with organic-matter particles in the aquifer. The composition of THg-bearing particles may vary, depending upon local geochemical conditions. 
Table 6. Concentrations of particulate mercury and mercury in unfiltered and filtered samples of domestic-well water collected throughout a day to simulate normal household water use, Burlington County, New Jersey, 2008-09.

[Particulate total mercury (PTHg) is calculated as the difference between total mercury in unfiltered water (UTHg) and total mercury in filtered water (FTHg). USGS, U.S. Geological Survey; $\mu \mathrm{g} / \mathrm{L}$, micrograms per liter]

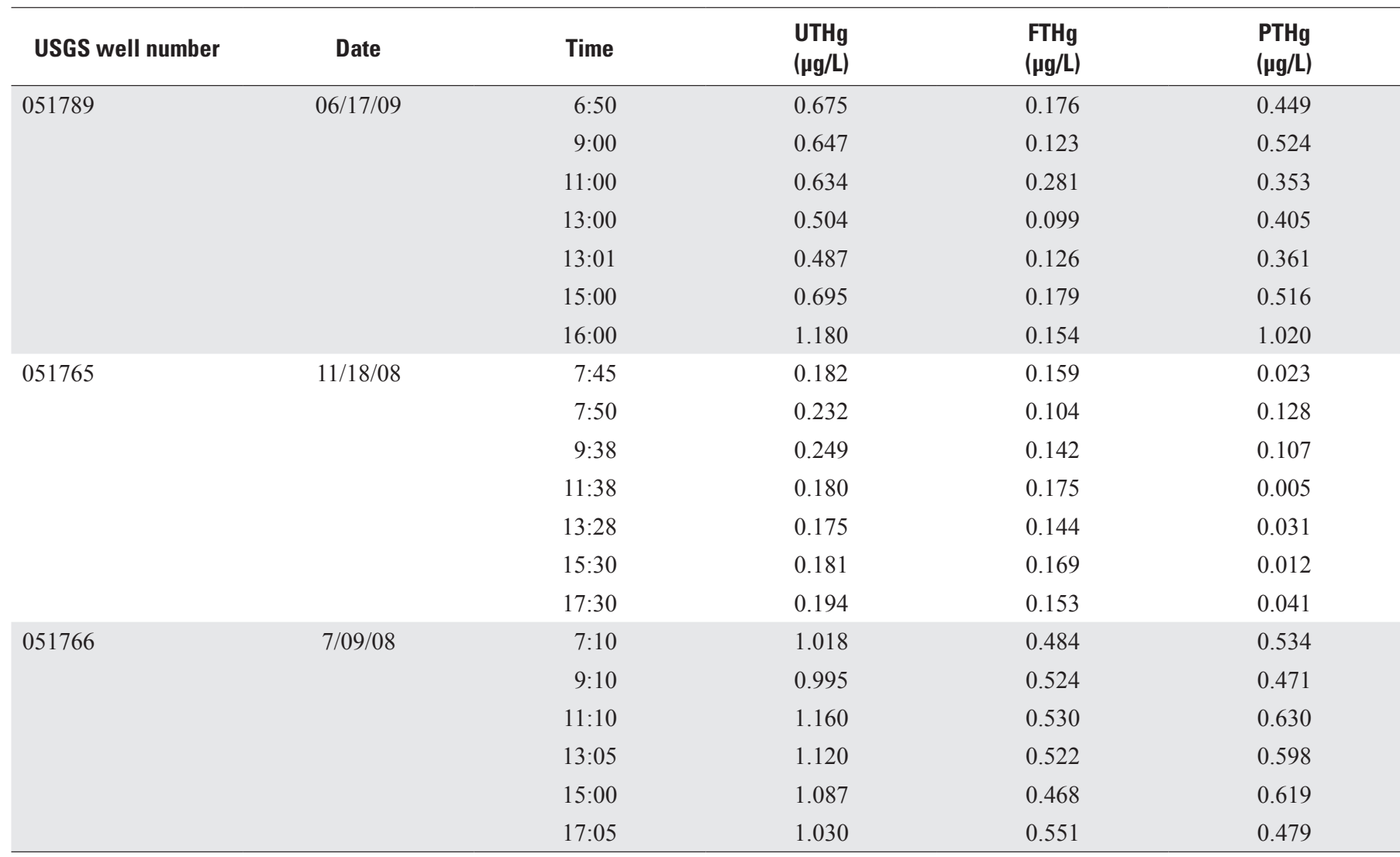

The form of THg not associated with particles greater than $0.45 \mu \mathrm{m}$ or with colloids less than $0.45 \mu \mathrm{m}$ has not been determined. If dissolved THg is present in the groundwater, speciation analysis (Barringer and others, 2006) indicates that, under reducing conditions, the $\mathrm{THg}$ could, at equilibrium, be present as $\mathrm{Hg}^{0} . \mathrm{Hg}^{0}$ is slightly soluble in water at $56 \mu \mathrm{g} / \mathrm{L}$ at 25 degrees Celsius (O'Neil, 2006), a concentration that is important with regard to drinking-water quality. As of 2012, USGS and NJDEP studies have not included direct measurement of $\mathrm{Hg}^{0}$ in groundwater samples. However, some samples of shallow groundwater and seeps to surface water collected in 2010 at the WJHTC site were analyzed for $\mathrm{Hg}^{0}$, and it was detected at low concentrations, ranging from 0.00023 to $0.00929 \mu \mathrm{g} / \mathrm{L}$ (Weston Solutions, written commun., 2011). Therefore, $\mathrm{Hg}^{0}$ presence in groundwater is confirmed, but more research is needed to determine the range of concentrations, distribution, and prevalence. In oxic conditions, other dissolved forms of $\mathrm{THg}$ are possible, such as $\mathrm{Hg}-\mathrm{Cl}$ or $\mathrm{Hg}$-dissolved organic carbon (DOC) complexes; results of geochemical modeling efforts indicate that an $\mathrm{HgCl}_{2}$ complex would be present only under highly oxic conditions, and $\mathrm{Hg}$-organic matter complexes would not be dominant (Barringer and others, 2006).
All the samples collected from the domestic wells are representative of water that is at the end of a localized flow path to the well; they may or may not be of water from along a regional flow path. The chemistry of that water may offer clues to the geochemical environments through which the water has passed on its way to a well, but given the reactivity of THg, it is seldom if ever possible to determine the various forms of THg that have existed along either the local flowpath or a regional flow path from the chemistry of a domestic-well water sample.

\section{Other Constituents}

Relations between THg and various dissolved constituents in well-water samples have been variable. During a USGS/NJDEP cooperative study (Barringer and others, 2005), 105 domestic wells completed in the CKKD were sampled; these included wells chosen specifically because of the land use in a buffer zone surrounding the well and wells chosen randomly. Positive and statistically significant relations between $\mathrm{THg}$ and $\mathrm{Cl}^{-}$and $\mathrm{NO}_{3}{ }^{-}$were found for well waters containing $\mathrm{THg}$ at concentrations up to $0.10 \mu \mathrm{g} / \mathrm{L}$ but were 

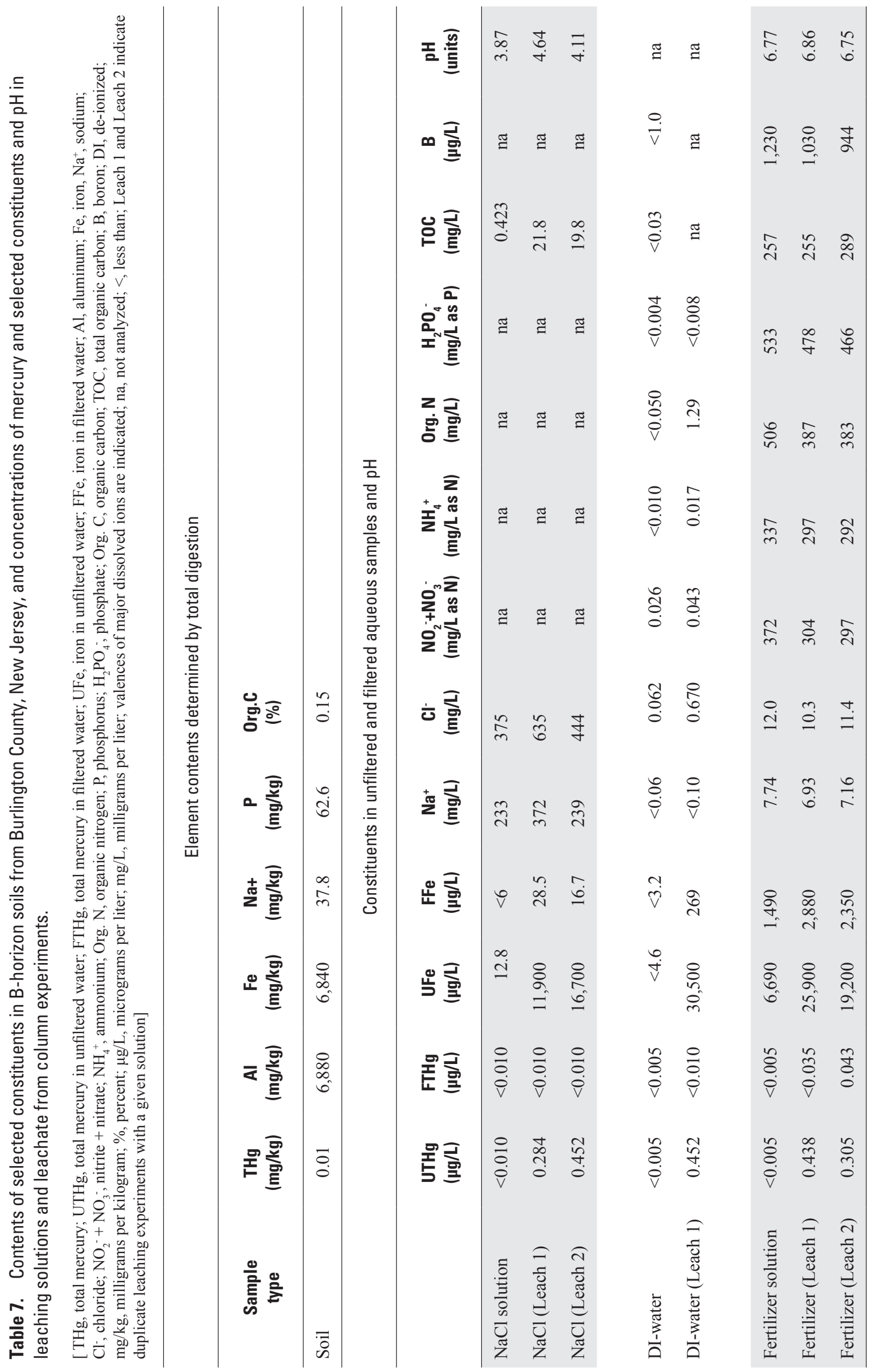

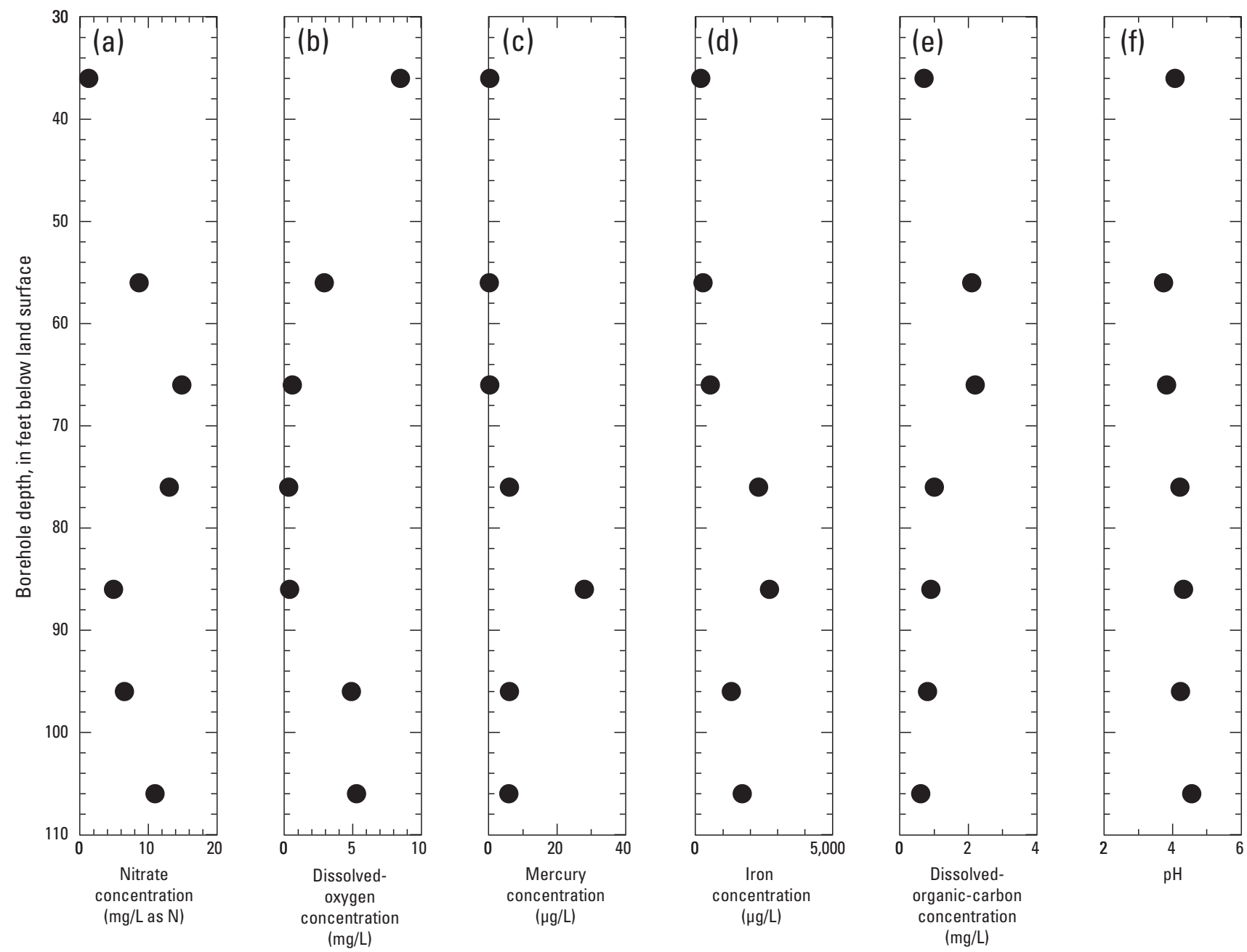

Figure 6. Concentrations of (a) nitrate, (b) dissolved oxygen, (c) mercury, (d) iron, and (e) dissolved organic carbon, and (f) pH in groundwater samples from the Kirkwood-Cohansey aquifer system, collected at discrete intervals with a screened augur, showing increase of iron and mercury concentrations with onset of reducing conditions downgradient from an abandoned septic leach field, Franklin Township, Gloucester County, New Jersey. (Modified from Barringer and MacLeod, 2001; mg/L, milligrams per liter; $\mu \mathrm{g} / \mathrm{L}$, micrograms per liter; N, nitrogen.).

not found where THg concentrations exceeded $0.10 \mu \mathrm{g} / \mathrm{L}$. In several of the USGS-led studies, relations between THg and DOC were variable, some showing positive relations, others not (Barringer and others, 2005, 2006). In general, the highest concentrations of $\mathrm{THg}$, including those that exceeded the MCL, have not shown strong relations with other dissolved constituents. One reason for this may be that, where THg is found at contaminant levels, the high concentrations are due mainly to THg-bearing particles. In such cases, statistical relations between concentrations of $\mathrm{THg}$ (mostly not dissolved) and concentrations of dissolved constituents are unlikely to be strong. Another reason for a lack of relations between high concentrations of THg and other constituents may be that the domestic well-water samples represent groundwater that is at the end of a flow path along which THg from subsoils and aquifer sediments may continue to be removed and released to groundwater during various biogeochemical reactions. Other constituents, such as $\mathrm{Cl}^{-}$, with no source in the aquifer matrix (Yuretich and others, 1981; Szabo and others, 2010a) may not be added along the flowpath but instead are gradually diluted; this is in contrast to $\mathrm{THg}$, which may originate in the soils and sediments. An indication of this possible soil or sediment source for THg is shown in Barringer and others (2006) who report the observation of higher concentrations of $\mathrm{THg}$ at the water table downgradient from septic leachfields than in the septage within the septic tank. One reason for a lack of relations between THg and DOC in groundwater could be the effects from other constituents such as $\mathrm{Cl}^{-}$, which interferes with the complexation of $\mathrm{Hg}$ with organic carbon (Wu and others, 2004). Further, Haitzer and others (2002) show binding of $\mathrm{Hg}$ to organic matter (OM) becomes less strong as the $\mathrm{Hg} / \mathrm{OM}$ ratio increases to greater than $10 \mu \mathrm{g}$ of $\mathrm{Hg} / \mathrm{mg} \mathrm{OM}$; the $\mathrm{Hg} / \mathrm{DOC}$ ratio is greater than 10 for some samples of groundwater from domestic wells (Barringer and others, 2006). 
Redox transformations along flow paths affect not only THg, but other redox-sensitive constituents as well, such as $\mathrm{N}$. Where differing redox conditions are encountered along a flow path, $\mathrm{N}$ species in the system may be altered, from ammonium $\left(\mathrm{NH}_{4}^{+}\right)$to $\mathrm{NO}_{3}^{-}$, for example. The same is true of sulfate $\left(\mathrm{SO}_{4}^{2-}\right)$; because many of the domestic well-water samples contained low (less than $1 \mathrm{mg} / \mathrm{L}$ ) to undetectable concentrations of $\mathrm{SO}_{4}^{2-}$, it appears that sulfate-reducing conditions may have been encountered along flow paths, likely within septiceffluent plumes, as found in one area study (Barringer and others, 2006). Septic-system effluent clearly can affect local geochemical environments, adding organic carbon, nitrogen, and sulfur, thus stimulating microbial activity and creating reducing conditions as organic carbon is oxidized. Additions of surfactants also may affect the behavior of particles in the aquifer (Barringer and others, 2006; Barringer and Szabo, 2006). Additionally, the influx of septic-system effluent could cause mounding at the water table, possibly affecting the flow direction of the shallow groundwater.

The geochemical speciation modeling (Barringer and others, 2006; Barringer and Szabo, 2006) that indicated possible presence of $\mathrm{Hg}^{0}$ also indicated that $\mathrm{Hg}-\mathrm{Cl}$ complexes were of negligible importance in the waters analyzed when Hg reduction or $\mathrm{Hg}$ complexation with organic matter was considered. In some speciation modeling, $\mathrm{Hg}$-organic carbon complexes were calculated. Nevertheless, relations between THg and DOC have not always been found to be strong. In the study at Squankum Branch, the relations between the highest THg concentrations in groundwater and ultra-violet absorbance at 254 nanometers (UV254, an indicator of DOC aromaticity) were found to be negative - a relation that is opposite to that found for surface waters at several North American sites (Shanley and others, 2008). Relations between THg and organic matter in the Coastal Plain appear to be complex, and it is not clear under what geochemical conditions DOC plays a role in the mobility of THg in groundwater. It may be that binding of THg to organic carbon in the CKKD is inhibited by acidic conditions and the high concentrations of $\mathrm{Cl}^{-}$(Wu and others, 2004), or binding may be inhibited because the $\mathrm{Hg} / \mathrm{DOC}$ ratio is greater than $10 \mu \mathrm{g} \mathrm{Hg} / \mathrm{mg}$ DOC (Haitzer and others, 2002) in water along some flowpaths. In samples of the uppermost mineral soils (A horizons) and aquifer sediments, however, there appears to be a positive relation between $\mathrm{THg}$ and $\mathrm{OM}$ (Barringer and Szabo, 2006).

As mentioned earlier, a positive relation between $\mathrm{THg}$ and $\mathrm{Fe}$ was observed for residential subsoils (B horizons), and the same relation occurred for leachfield effluent samples (Barringer and others, 2006). Although Hg (from atmospheric deposition and, most likely, from former pesticide and fertilizer use) is associated with $\mathrm{OM}$ in the A horizons of residential areas (Barringer and Szabo, 2006), some of the $\mathrm{Hg}$ is dislocated and moved to the Fe-rich B-horizon soils or deeper into the $\mathrm{C}$ horizon of barely altered sediments in the unsaturated zone. In these subsoils and sediments, THg apparently is sorbed to the ubiquitous Fe hydroxides that coat sediment grains.
It is hypothesized that septic-system effluent removes and mobilizes $\mathrm{Hg}$ from Fe hydroxides. In the environment of a recently abandoned septic-system leachfield, concentrations of $\mathrm{Fe}$ and $\mathrm{THg}$ increased in water as concentrations of DO decreased (fig. 6; Barringer and MacLeod, 2001). Further, a linear and positive relation was found between $\mathrm{THg}$ and $\mathrm{Fe}$ concentrations in filtered septic-system effluent and groundwater samples from low-oxygen environments (Barringer and others, 2006). These relations between THg, Fe, and DO are interpreted as demonstrating reductive dissolution of the hydroxides and release of the sorbed $\mathrm{THg}$.

Volatile organic compounds (VOCs), mainly chlorinated solvents, have a nearly ubiquitous presence in groundwater at the residential areas where well water contains $\mathrm{Hg}$ contamination. The VOCs occur in some cases, at concentrations substantially greater than the respective MCLs. Nevertheless, the cases in which water from a given well contains both $\mathrm{Hg}$ and VOC contamination are relatively few. This lack of direct association was particularly evident in the large database compiled for sampling of Gloucester County wells (Donald Schneider, Gloucester County Health Department, written commun., 2006). Relatively weak statistical relations between presence of VOCs and presence of $\mathrm{Hg}$ at contamination levels were found for six residential sites in Atlantic County (Barringer and Szabo, 2006). The VOCs and THg appear to derive from different sources; a likely source of the VOCs, chlorinated solvents, is septic-system cleaners used until the early 1970s (Robert A. Gallagher, New Jersey Department of Environmental Protection, oral commun., 2005); other sources (commercial effluents, for example) are likely in the residential areas as well. VOCs could play a role in facilitating $\mathrm{Hg}$ mobility in the CKKD, perhaps by influencing redox conditions during biodegradation. With concentrations of daughter products, such as 1,2-dichloroethylene, present in the groundwater, the VOC concentrations likely are affected directly by biodegradation over time, whereas microbial activity may lead to biotransformations of inorganic compounds that affect both $\mathrm{THg}$ speciation and complexation. A study of $\mathrm{Hg}$ in Delaware groundwater (Koterba and others, 2006) clearly illustrates a similar coincidence between VOCs and Hg occurrence.

\section{Methylmercury}

Data on MeHg in New Jersey Coastal Plain soils are limited. In residential soils, the $\mathrm{MeHg}$ contents of upper (A-horizon) soils were found to be less than $0.001 \mathrm{mg} / \mathrm{kg}$ and typically about $0.0001 \mathrm{mg} / \mathrm{kg}$ (Barringer and Szabo, 2006). The MeHg content of streambed sediments has, to these authors' knowledge, been determined only for the streams that border the WJHTC.

Well-water samples collected from the CKKD by southern New Jersey county agencies and NJDEP are not routinely analyzed for MeHg. Results of analyses of water from five wells sampled by NJDEP in the early 1990s indicate high concentrations of $\mathrm{MeHg}(0.100-0.137 \mu \mathrm{g} / \mathrm{L}$ ) are present (Murphy 
and others, 1994), but subsequent sampling of 33 domestic wells by the USGS for the National Water Quality Assessment ( NAWQA) Program have not yielded comparable concentrations. The USGS MeHg dataset for groundwater in the CKKD is small, but concentrations typically are less than $0.001 \mu \mathrm{g} / \mathrm{L}$ or are not detected at $0.0004 \mu \mathrm{g} / \mathrm{L}$.

The median concentration of $\mathrm{SO}_{4}^{2-}$ in relatively pristine groundwater from the CKKD in undeveloped areas was $5.6 \mathrm{mg} / \mathrm{L}$, but in some residential areas, concentrations were either greater than those background levels or are not detectable (Barringer and others, 2006). The presence of aqueous sulfide (Barringer and others, 2006) and the low (less than $1 \mathrm{mg} / \mathrm{L}$ ) to undetectable concentrations of $\mathrm{SO}_{4}{ }^{2-}$ in some samples of domestic well water collected by USGS (Barringer and Szabo, 2006) likely are indicative of sulfate-reducing conditions in the CKKD. However, such conditions may not lead to the methylation of mercury, which is a reaction resulting from metabolic activity by sulfate-reducing bacteria (Gilmour and Henry, 1991). It may be that, in the CKKD, the Hg is in a form unavailable to the microbes $\left(\mathrm{Hg}^{0}\right.$, perhaps) or that, where affected by septic-system effluent, the high salinity of some groundwater inhibits the methylation process as shown by Barkay and others (1997). It is also possible that the time spans in which conditions are conducive to sulfate reduction are short (transient conditions) and methylation of $\mathrm{Hg}$ is difficult to initiate.

In areas of the Coastal Plain underlain by the CKKD sediments, $\mathrm{MeHg}$ in streamwater has been determined only for the mainstem and tributaries of the GEHR in USGS/NJDEP cooperative studies (Barringer and others, 2010a; fig. 4). Concentrations of MeHg in GEHR streamwater typically were less than $0.001 \mu \mathrm{g} / \mathrm{L}$ in downstream, wetlands parts of the watershed, but concentrations were as high as $0.003 \mu \mathrm{g} / \mathrm{L}$ in streamwater from the upstream, urban part of the watershed (Barringer and others, 2010a). Given its areal extent and range of land uses, the GEHR watershed is likely representative of other Coastal Plain streams that flow over CKKD sediments. Thus, the MeHg concentrations measured in GEHR waters probably are representative of those found under ambient conditions elsewhere in the region, as further described by Brumbaugh and others (2001).

\section{Summary of Mercury Found at the William J. Hughes Technical Center}

\section{Site Description and History}

The 5,000-acre William J. Hughes Technical Center (WJHTC) site is within the boundary of the Atlantic City International Airport in Atlantic County, New Jersey, which is located to the west-northwest of the two Atlantic City reservoirs (Upper Reservoir and Lower Reservoir; fig. 7). The part of the airport area that extends between the two branches of Absecon Creek was leased by Atlantic City to the U.S. Navy in the 1940s and 1950s. During that time, various operations involving aircraft and weapons were carried out that included use of mercury (TRC, 2005). As a result, liquid mercury was stored at the site; much of the $\mathrm{Hg}$ is thought to have been salvaged after the U.S. Navy left the site in 1958 and when the buildings were cleaned out and (or) demolished during 1959-62 (TRC, 2005). The Federal Aviation Administration (FAA) now owns the site, which was placed on the National Priorities List (Superfund) in 1990.

The airport and the WJHTC are underlain by sediments of the Cohansey Formation, the upper unit of the CKKD sediments. The Cohansey Formation is predominantly sandy but contains clay layers, some of which are areally extensive at the WJHTC site (TRC, 2010), as evidenced by local area clay pits, highly dissected relief, and determinations of local subsurface extent from well logs, which indicate the presence of an extensive 15-ft-thick dark gray clay layer (TRC, 2010). Land at the site slopes to the North and South Branches of Absecon Creek (NBAC and SBAC, respectively), both of which were dammed in 1936 to form the reservoirs. The area within the watershed of these two creek branches is known as Area $U$ (fig. 7). Most of the detailed Hg investigations have been carried out in Area U. Hg contamination was substantially more prominent in the watershed of the SBAC, which has received the most focused investigation. $\mathrm{Hg}$ contamination of the creek watersheds is of concern because water from the creeks flows into the public reservoirs.

There are residential areas on the uplands to the north of NBAC and to the south of SBAC; these areas are composed of housing developments and trailer parks built mainly in the 1960s through the 1970s, generally on former agricultural land (residential sites 2, 3, 5, and 17 in Barringer and others, 1997; figs. 7 and 8). Within these unsewered communities in the 1980 s, water from some of the domestic wells was found to contain concentrations of THg that exceeded the MCL of $2 \mu \mathrm{g} / \mathrm{L}$. In the residential area to the south of the WJHTC site (site 2 in fig. 7; Barringer and others, 1997), THg exceeded the MCL in water from 4 monitoring wells at a waste-transfer station and in water from 28 of the 216 domestic wells sampled by NJDEP during 1988-92 (fig. 9). The domestic wells were completed at depths of 40 to $180 \mathrm{ft}$ below land surface; most wells were completed at about $85 \mathrm{ft}$. Prior to sampling at site 2, samples collected from more than 300 wells in site 3, another residential area (Barringer and others, 1997) to the southeast, by the Atlantic County Health Department indicated that about 20 percent of those wells yielded water with $\mathrm{THg}$ concentrations in excess of the MCL. Wells in this residential development (where well-log data are available) were completed at depths of 60 to $130 \mathrm{ft}$; most were completed at about $100 \mathrm{ft}$. During the same time period, wells withdrawing water with $\mathrm{THg}$ concentrations substantially greater than background levels and, in numerous cases, exceeding the MCL, were reported in residential areas to the north and northeast of the WJHTC (fig. 7), as well as several farther to the east-southeast 


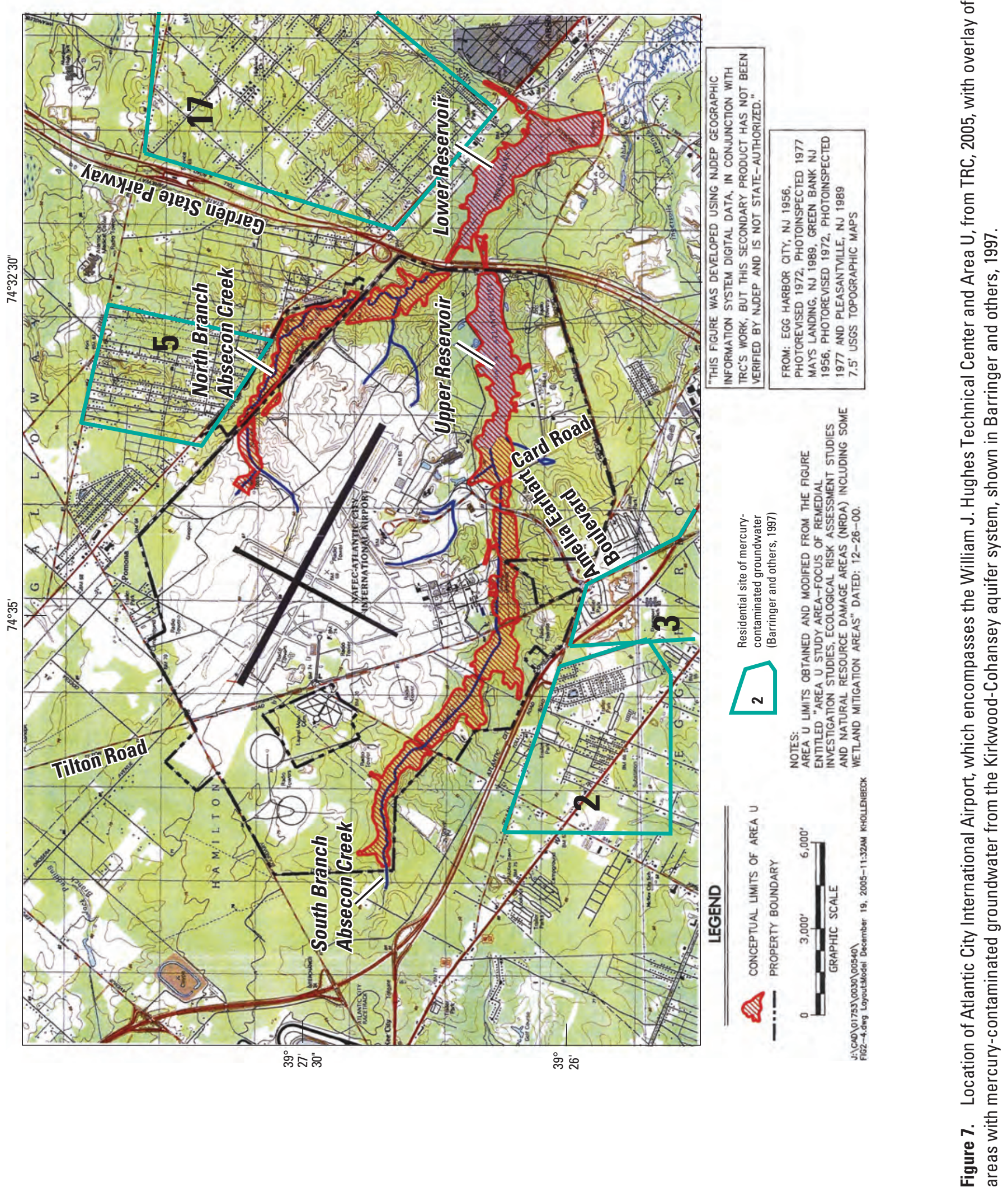


THg discovered in domestic-well water

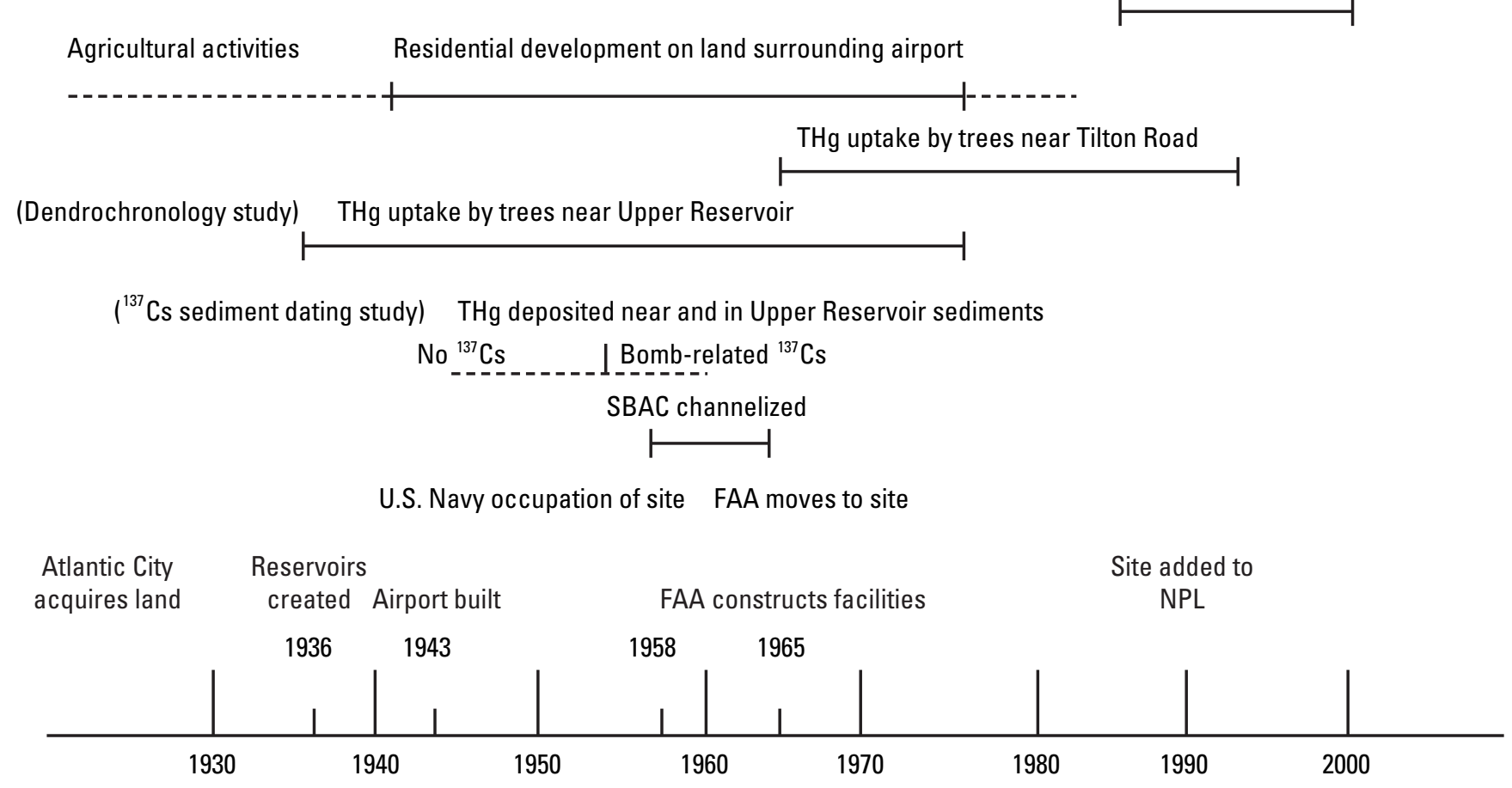

Figure 8. Time line indicating various events at and in the vicinity of the William J. Hughes Technical Center site, New Jersey. (THg, total mercury; ${ }^{137} \mathrm{Cs}$, cesium-137 isotope; NPL, national Priorities List (Superfund); FAA, Federal Aviation Administration; SBAC, South Branch Absecon Creek.)

and southeast (fig. 10). Thus, the airport and WJHTC are surrounded by residential areas where groundwater was discovered to be contaminated with THg in the mid-to-late $1980 \mathrm{~s}$ and early 1990s. (To these authors' knowledge, affected wells have been sealed, and no recent sampling in these areas has occurred; therefore, it is not known whether the groundwater is still contaminated more than two decades later.)

\section{Area Hydrology}

On the basis of local topography and the water-table map of Clark and Paulachok (1989), flow directions of shallow groundwater from the residential areas were interpreted to be toward the NBAC, SBAC, and the reservoirs (fig. 10; Barringer and others, 1997), although the direction of deep regional flow likely is toward the ocean. Measurements in 2008 of hydraulic heads in piezometers placed along the SBAC in the area west of Tilton Road indicate that shallow groundwater from the south is draining to the deeper aquifer rather than discharging to the stream. Immediately downstream, however, shallow groundwater from the north (from the airport area) is discharging to the SBAC (Weston Solutions, 2009). In small streams of the Coastal Plain, the directions of flow between shallow groundwater and streams can change depending on antecedent conditions; following rainfall, parts of a stream may lose flow to groundwater for several days until infiltration raises the hydraulic head in the aquifer (Johnsson and Barringer, 1993). It is possible that similar changes in shallow flow might be observed along some parts of the SBAC if hydraulic heads were monitored over a long period of time. The general direction of groundwater flow at shallow to intermediate depths (roughly 27 to $32 \mathrm{ft}$ below land surface) from north of the SBAC watershed in the area just east of Tilton Road was determined to be in a generally east-southeast to easterly direction, from the airport runway area towards the SBAC and the reservoirs (TRC, 2010).

\section{Mercury in Soils and Sediments}

Most of the investigations of $\mathrm{Hg}$ at the WJHTC focused on the area of the SBAC where contaminant levels of $\mathrm{Hg}$ were found to be the highest. Soil and sediment Hg concentrations in the watershed of the NBAC have been generally low but highly variable; typical concentrations were less than $0.3 \mathrm{mg} / \mathrm{kg}$, but occasionally much higher concentrations were observed during sampling in 2008 (Weston Solutions, 2009).

During the late 1950s and early 1960s, the SBAC was channelized (fig. 8), and disturbance of soils and sediments along the once meandering stream occurred during this time, just prior to major land-use change from forested land and 

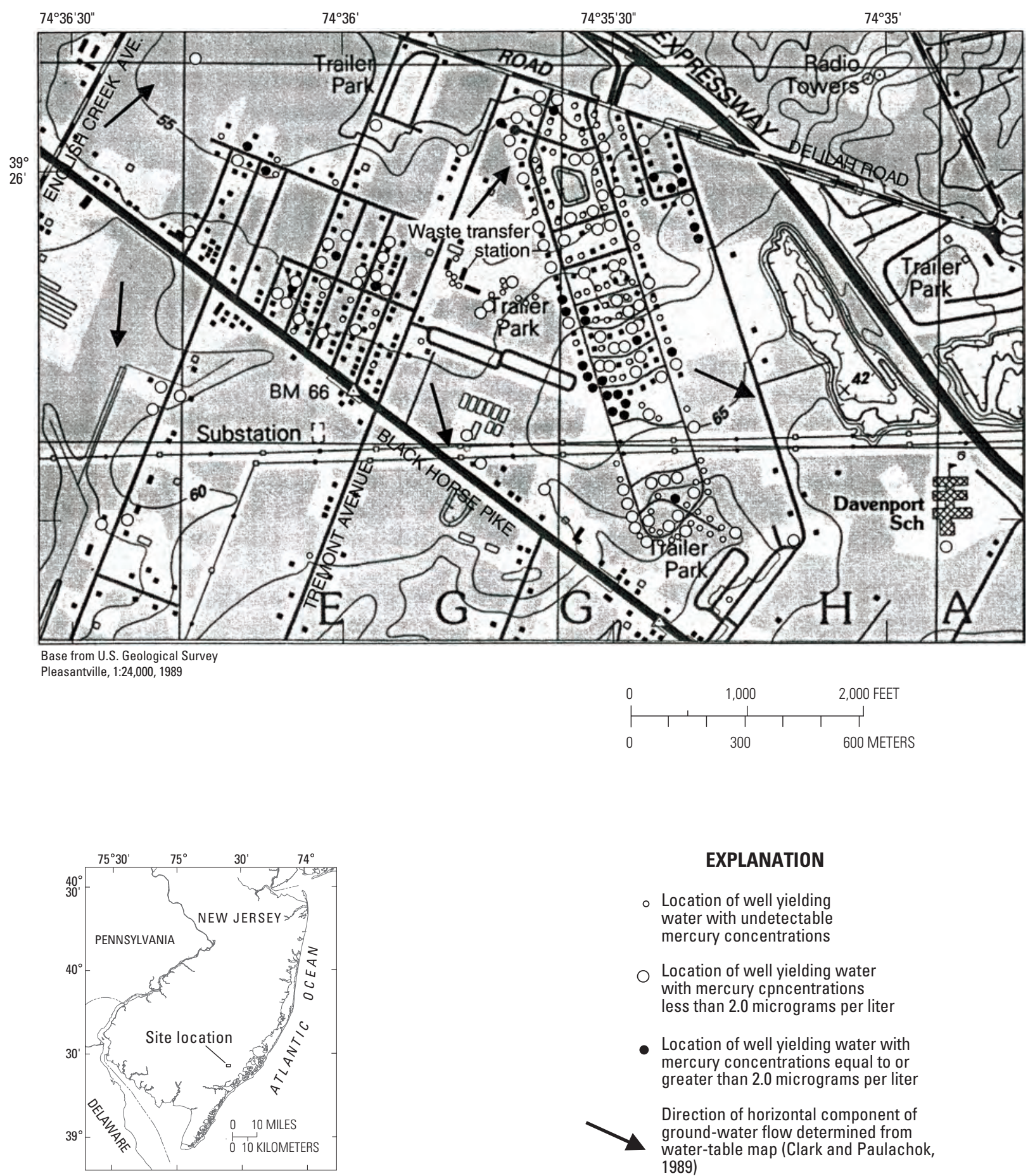

Figure 9. Concentrations of mercury in groundwater from domestic wells completed in the Kirkwood-Cohansey aquifer system at a residential area (site 2) to the southwest of the William J. Hughes Technical Center site, Atlantic County, New Jersey, and direction of the horizontal component of groundwater flow determined from water-level data. (From Barringer and others, 1997) 

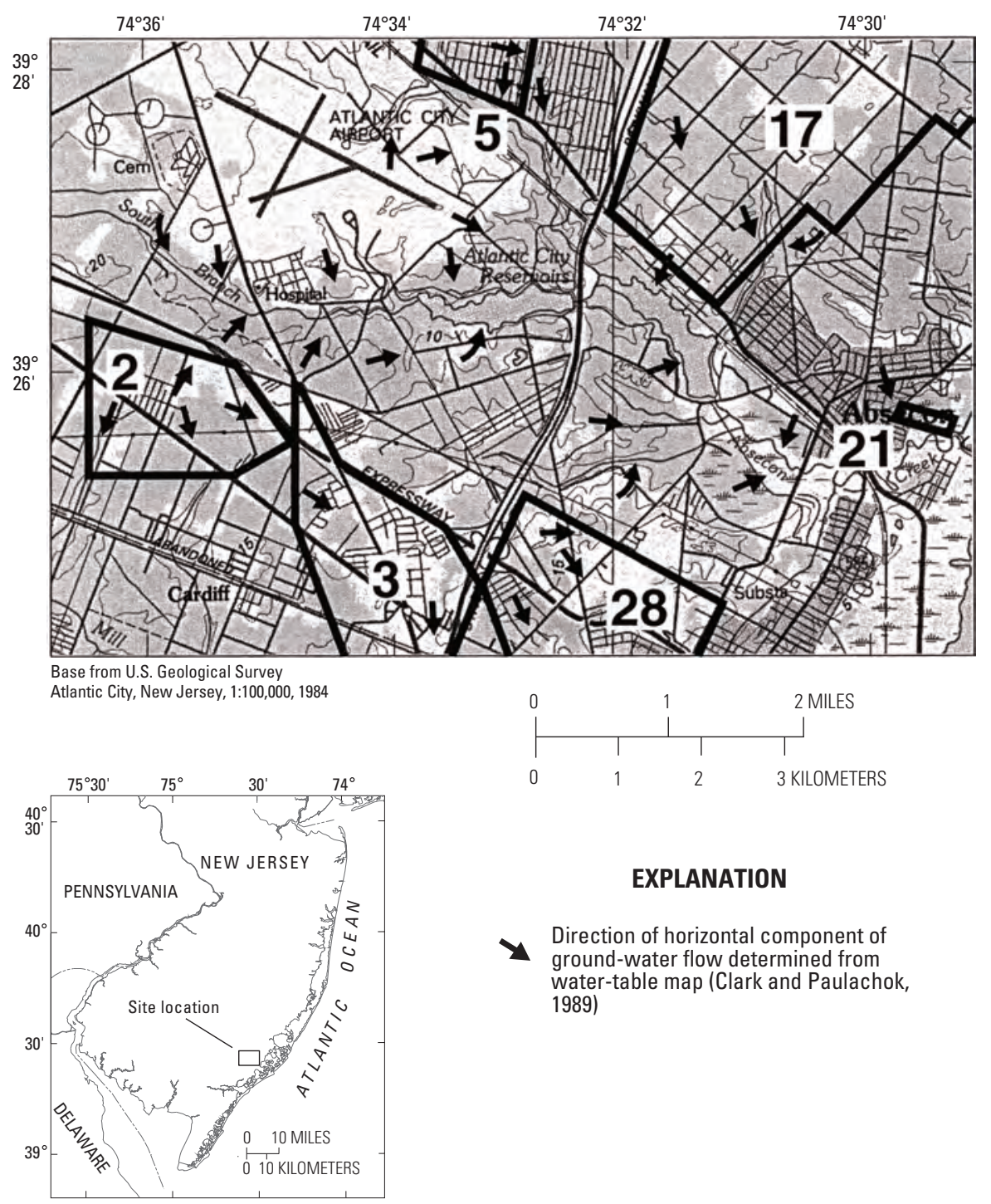

\section{EXPLANATION}

Direction of horizontal component of ground-water flow determined from water-table map (Clark and Paulachok, 1989)

Figure 10. Area surrounding the Atlantic City International Airport in New Jersey, which encompasses the William J. Hughes Technical Center site, groundwater-flow directions in the Kirkwood-Cohansey aquifer system, and six residential sites where domestic wells yielded water containing total mercury at concentrations that approached or exceeded the New Jersey maximum contaminant level of 2 micrograms per liter. (Numbers correspond to numbers in Barringer and others, 1997; map is from figure 33 of Barringer and others, 1997)

agricultural land to residential development on the highlands surrounding the airport site. THg contents were found to be as high as $200 \mathrm{mg} / \mathrm{kg}$ (Bopp, 2005) in soils and sediments of the abandoned meander of the SBAC east of Amelia Earhart Boulevard and, on the basis of isotope concentrations of cesium-137 $\left({ }^{137} \mathrm{Cs}\right)$ and lead-210 $\left({ }^{210} \mathrm{~Pb}\right)$ found in the soils, the deposition of THg is thought to have occurred during the Navy occupation of the site (TRC, 2010). The THg contents ranged up to $555 \mathrm{mg} / \mathrm{kg}$; levels well above regional background levels $(0.015 \mathrm{mg} / \mathrm{kg}$ or less) were consistently reported during sampling in 2004 and earlier at the stream meander between Amelia Earhart Boulevard and Card Road (TRC, 2005; Weston Solutions, 2009). Later sampling in 2008 confirmed that the THg contents of soils and sediments in this area were particularly high (up to $88.4 \mathrm{mg} / \mathrm{kg}$ ). Soil and sediment sampling in 2008 by Weston Solutions (2009) along the SBAC in the area west of Tilton Road reveal THg contents of the sediments there were an order of magnitude or more lower than THg in soils at the stream meander near Amelia Earhart Boulevard (ranging up to $8.24 \mathrm{mg} / \mathrm{kg}$ ) but much higher than regional background levels $(0.015 \mathrm{mg} / \mathrm{kg}$ or less). Given that sediment contents of $\mathrm{THg}$ were generally highest at abandoned 
SBAC meanders, particularly in the area between Amelia Earhart Boulevard and Card Road, it is presumed that deposition of $\mathrm{Hg}$ occurred along the original channel of the SBAC before channelization occurred. The THg concentrations in tree rings of Atlantic White Cedars at this site indicate that the 1940s and mid-to-late 1950s were times when elevated concentrations of THg were taken up by trees in the SBAC watershed (TRC, 2005), although uptake of THg by trees near Tilton Road appears to have occurred later, during the mid-1960s to mid-1990s. Because Eastern Red Cedar has preserved patterns of $\mathrm{Hg}$ incorporation that correspond to timing of known emissions (Ralph Turner, RT Geosciences, Inc., written commun., 2004), Hg uptake is presumed to be well-preserved in rings of the Atlantic White Cedar; therefore, the tree-ring dates for greater uptake of $\mathrm{Hg}$ by trees in the SBAC watershed are likely to be reliable.

The 1940s and early 1950s were times when crops were being grown on the highlands surrounding the SBAC and the airport (Barringer and others, 1997); applications of mercurial pesticides may have occurred during this period. Whether runoff from the agricultural land could have carried THg from pesticide applications to the streams is not known, nor is it known whether shallow groundwater from the agricultural areas would have discharged to the NBAC and SBAC, potentially carrying $\mathrm{THg}$ derived from leached mercurial pesticides. Residential development began on the agricultural land, mostly in the 1960s, and may have been instrumental in mobilizing $\mathrm{Hg}$ already in the soils. During this period and afterwards, Hg released to groundwater may have been transported downgradient and discharged into parts of the SBAC, probably after channelization was completed. In the absence of any groundwater data for the WJHTC site from this time period, this hypothesis cannot be confirmed.

THg contents of sediment samples collected in 2008 along the channelized SBAC and in its abandoned meanders between Tilton Road and the Upper Reservoir indicate that THg was highest (up to $88.4 \mathrm{mg} / \mathrm{kg}$ ) in the shallow (1- to 6-inch depth) sediments in the meanders, whereas the THg contents of sediments in the channelized stream are lower (Weston Solutions, 2009). Because of sediment accumulation at road crossings, stream sediments immediately upstream from crossings tended to have higher contents of $\mathrm{Hg}$ than sediments in other stream reaches. In the Upper Reservoir, THg contents of bottom sediments, which in general are rich in OM, were elevated, ranging as high as $19.6 \mathrm{mg} / \mathrm{kg}$ at the upstream end; THg contents were substantially lower throughout much of the reservoir (Weston Solutions, 2009), however. Sulfide was detected in a few samples, indicating reducing conditions were present in some parts of the reservoir bottom.

\section{Mercury in Groundwater and Streamwater}

Groundwater samples were collected from both banks of the NBAC and SBAC using piezometers and from wells installed in and adjacent to Area $U$ (the watersheds of the
NBAC and SBAC). However, relatively little attention was given to groundwater and streamwater in the watershed of the NBAC because early sampling efforts indicated $\mathrm{Hg}$ concentrations were lower in the NBAC watershed than in the SBAC watershed. In the SBAC watershed, unfiltered samples of groundwater collected in 1996 north of the SBAC between Tilton Road and the Upper Reservoir contained concentrations of THg of 23.6 and $26.7 \mu \mathrm{g} / \mathrm{L}$, most of which was particulate in form (TRC, 2010). Samples collected from monitoring wells both north and south of the SBAC channel, in some cases, contained $\mathrm{Hg}$ at greater than background levels, although not at contaminant levels of $2 \mu \mathrm{g} / \mathrm{L}$ or greater. Higher concentrations were found in some samples collected adjacent to the former meanders of the SBAC. Recently (2008) collected samples of groundwater from midstream seeps to the SBAC indicate that $\mathrm{THg}$ concentrations were variable, from background levels (less than $0.010 \mu \mathrm{g} / \mathrm{L}$ ) to a high of $8.9 \mu \mathrm{g} / \mathrm{L}$ (Weston Solutions, 2009). In general, the THg concentrations in samples from the wells and piezometers were highly variable. The highest $\mathrm{THg}$ concentration in recent (2008) samples $(6.97 \mu \mathrm{g} / \mathrm{L})$ was found in filtered groundwater (interstitial water) from beneath the SBAC channel in the area west of Tilton Road (Weston Solutions, 2009). Three other filtered samples from the area, collected at depths of 5 to $10 \mathrm{ft}$, contained THg at concentrations that exceeded the MCL, and two other samples contained $\mathrm{Hg}$ at concentrations exceeding $1 \mu \mathrm{g} / \mathrm{L}$. Overall, when both unfiltered and filtered samples were collected, substantial differences in concentrations indicate that much of the $\mathrm{Hg}$ in the groundwater is in particulate form. Some of the particulates may be sampling artifacts, as sample collection using a low-flow protocol was found to produce fewer particulates (TRC, 2010). (Decreasing the amount of particulates present as an artifact of purging also decreases the amount of particulate $\mathrm{Cu}, \mathrm{Pb}$, and other trace elements (Gibs and others, 2000).) Nevertheless, results of ultrafiltration of groundwater samples from the WJHTC site (with filters of pore size less than $0.1 \mu \mathrm{m}$ and less than $0.0015 \mu \mathrm{m}$ ) indicate that $\mathrm{Hg}$ was present on colloids, as well as on the larger particles filtered using $0.45-\mu \mathrm{m}$ pore-size filters (TRC, 2010).

Concentrations of THg in SBAC streamwater also were variable. One sample from a 2004 round of sampling contained $2.69 \mu \mathrm{g} / \mathrm{L}$ of THg, and other samples contained THg at concentrations of 0.256 and $0.954 \mu \mathrm{g} / \mathrm{L}$ (TRC, 2006). Interstitial water in the SBAC streambed in the area west of Tilton Road contained $\mathrm{THg}$ at concentrations that ranged from 0.14 to $5.45 \mu \mathrm{g} / \mathrm{L}$ (Weston Solutions, 2009).

A plume of chlorinated solvents in the shallow groundwater underlies part of the SBAC channel between Tilton Road and Amelia Earhart Boulevard. This plume has been, and is currently (2012) being, remediated through extraction wells, water treatment, and reinjection into wells to the southeast of Amelia Earhart Boulevard (TRC, 2010). It is not known what effect this may have on the chemistry and mobility of $\mathrm{Hg}$ in the groundwater and SBAC streamwater, but it appears from a recent investigation of groundwater concentrations that the 
extraction wells are drawing $\mathrm{Hg}$ from shallow depths more deeply into the aquifer in this area (TRC, 2010).

\section{Methylmercury in Sediment and Water}

Because the reservoirs supply drinking water to Atlantic City and the SBAC drains to the Upper Reservoir, levels of $\mathrm{MeHg}$ in sediments and water of the reservoirs were a matter of concern. The MeHg contents of sediment samples collected along the SBAC in 2008 were variable, ranging from $0.00011 \mathrm{mg} / \mathrm{kg}$ to $0.0266 \mathrm{mg} / \mathrm{kg}$. MeHg contents of sediments were higher above a depth of $1 \mathrm{ft}$, and lower in deeper sediments (Weston Solutions, 2009). The MeHg content of sediment samples from the upstream end of the Upper Reservoir was high (up to 0.0977), but the content of most of the reservoir sediment samples was low (less than $0.01 \mathrm{mg} / \mathrm{kg}$ ). Concentrations of $\mathrm{MeHg}$ in two samples of reservoir water were 0.000877 and $0.00059 \mu \mathrm{g} / \mathrm{L}$ (Weston Solutions, 2009), and elevated levels in fish tissue (up to $6.5 \mathrm{mg} / \mathrm{kg}$ ) have been found (TRC, 2010).

\section{Comparison of Mercury Levels at the William J. Hughes Technical Center with Levels Found Regionally in Southern New Jersey}

The THg contents of soils and sediments at several identified "hotspots" in the SBAC watershed at the WJHTC site were substantially greater than those found in soils and streambed sediments during regional investigations. These data may be indicative of a source of THg at the WJHTC that is not found elsewhere in the region.

The range of concentrations of THg found to date (2012) in groundwater at the WJHTC covers only part of the substantial range of concentrations $(0.0004-82 \mu \mathrm{g} / \mathrm{L})$ found regionally in domestic well water. Both regionally and locally at the WJHTC, some of the $\mathrm{Hg}$ in groundwater is in particulate form, which affects the mobility of $\mathrm{Hg}$. If $\mathrm{THg}$ is moving mainly as a particle or colloid, it may be less likely to participate in biogeochemical reactions while being transported by the groundwater. It appears that THg in groundwater at the WJHTC behaves geochemically in the same manner as it does regionally. Given the likelihood that disturbance of soils within the southern New Jersey region plays a role in mobilizing THg, the fate and transport of THg at the WJHTC is undoubtedly affected by channelization of the SBAC, road incisions that cross the stream channel, accumulation of sediments upstream from the reservoirs, and dams that form the reservoir system. Whether some portion of the $\mathrm{Hg}$ found in the reservoir sediments and water is contributed by groundwater discharge currently is not known; surface flow appears to contribute $\mathrm{Hg}$ to the Upper Reservoir.
Concentrations of THg in streamwater at the WJHTC were variable. In a few streamwater samples from the SBAC, $\mathrm{THg}$ was measured at concentrations as high as $2.6 \mu \mathrm{g} / \mathrm{L}$. Concentrations exceeding $2 \mu \mathrm{g} / \mathrm{L}$ were not measured in streamwater samples elsewhere in the Coastal Plain. As of 2012, the highest concentration, $0.25 \mu \mathrm{g} / \mathrm{L}$, was present in a water sample collected by NJDEP from Squankum Branch in Gloucester County.

If the THg in the soils, sediments, surface water, and groundwater at the WJHTC is derived from $\mathrm{Hg}^{0}$, as is indicated by the anecdotal evidence gathered by TRC (2005), then initially, $\mathrm{THg}$ from this source could be expected to behave differently than the ionic $\mathrm{Hg}$ present in $\mathrm{HgCl}_{2}$ pesticides that likely were used on crops in the region. Ionic $\mathrm{Hg}$ would be easily complexed or sorbed to particles, as evidenced by data gathered during various USGS investigations (Barringer and MacLeod, 2001; Barringer and others, 2006; Barringer and Szabo, 2006). On the other hand, $\mathrm{Hg}^{0}$ would likely become oxidized in order to sorb to particles. This apparently has occurred, insofar as groundwater at the WJHTC has been shown to contain particles and colloids, and no discoveries of $\mathrm{Hg}$ in liquid elemental form have been reported for the soil and sediment samples. Once in ionic form, the THg at the WJHTC would likely behave in the environment much as the THg in the region is thought to behave- - binding/complexing with organic matter and sorbing to Fe hydroxides, for example. The main similarities and differences in the levels of $\mathrm{THg}$ and $\mathrm{MeHg}$ at the WJHTC and regionally are summarized in table 8 . 
Table 8. Summary of similarities and dissimilarities between mercury levels at the William J. Hughes Technical Center and regionally in the Coastal Plain of New Jersey.

[THg, total mercury; MeHg, methylmercury; mg/kg, milligrams per kilogram; <, less than; $\leq$, less than or equal to; $\mu \mathrm{g} / \mathrm{L}$, micrograms per liter; $\mu \mathrm{m}$, micrometer; SBAC, South Branch Absecon Creek; MCL, maximum contaminant level in drinking water; NJDEP, New Jersey Department of Environmental Protection]

\begin{tabular}{|c|c|}
\hline William J. Hughes Technical Center & New Jersey Coastal Plain Region \\
\hline \multicolumn{2}{|c|}{ Soils and sediments } \\
\hline $\begin{array}{l}\text { THg contents of disturbed soils and sediments are highly variable. } \\
\mathrm{THg} \text { contents approaching or reaching } 100 \mathrm{mg} / \mathrm{kg} \text { in the SBAC } \\
\text { watershed are substantially greater than the } \mathrm{THg} \text { contents found } \\
\text { in regional soils and sediments. } \mathrm{MeHg} \text { content of soils and sedi- } \\
\mathrm{ments} \text { is generally }<0.001 \mathrm{mg} / \mathrm{kg} \text {, but has been found as high as } \\
0.0977 \mathrm{mg} / \mathrm{kg} \text { in reservoir sediments, and up to } 0.0266 \mathrm{mg} / \mathrm{kg} \text { in } \\
\text { SBAC sediments. }\end{array}$ & $\begin{array}{l}\text { THg contents of disturbed residential soils typically are } \\
<0.50 \mathrm{mg} / \mathrm{kg} \text {. Contents of undisturbed forest soils are about } \\
0.10-0.15 \mathrm{mg} / \mathrm{kg} \text {. Former agricultural soils } / \text { sediments with possible } \\
\text { pesticide residues contain about } 12 \mathrm{mg} / \mathrm{kg} \text { of } \mathrm{THg} \text {. Total and recover- } \\
\text { able } \mathrm{Hg} \text { contents of streambed sediments generally are } \leq 0.03 \mathrm{mg} / \mathrm{kg} \text {, } \\
\text { but in streams affected by urban inputs, contents increase to } \\
0.099 \mathrm{mg} / \mathrm{kg} \text {. Where inputs from former agricultural pesticides } \\
\text { may be present, contents are as great as } 1.59 \mathrm{mg} / \mathrm{kg} \text {. Limited data } \\
\text { indicate the } \mathrm{MeHg} \text { content of residential soils is }<0.001 \mathrm{mg} / \mathrm{kg} \text {. }\end{array}$ \\
\hline
\end{tabular}

\section{Groundwater}

Concentrations of THg in groundwater are variable. Background concentrations $(<0.01 \mu \mathrm{g} / \mathrm{L})$ are found. In the SBAC watershed, concentrations can exceed the New Jersey MCL ( $2 \mu \mathrm{g} / \mathrm{L})$ but have not been found to reach the high levels present regionally in domestic well water. A substantial portion of the $\mathrm{THg}$ is particulate, and colloidal THg $(<0.45 \mu \mathrm{m})$ has been found.
Concentrations of $\mathrm{THg}$ in water from domestic wells range from $0.0004 \mu \mathrm{g} / \mathrm{L}$ to $82 \mu \mathrm{g} / \mathrm{L}$. In some samples, particulate $\mathrm{Hg}$ is present. Sampling for colloidal $\mathrm{Hg}$ has not been carried out.

Except for a few early samples collected by NJDEP, concentrations of $\mathrm{MeHg}$ in well water have been found at $<0.001 \mu \mathrm{g} / \mathrm{L}$, but data are limited to fewer than 100 wells sampled.

\begin{tabular}{l|l}
\hline \multicolumn{2}{c}{ Surface Water } \\
\hline $\begin{array}{l}\text { Concentrations of THg in streamwater are variable and span the } \\
\text { range of concentrations found regionally. Concentrations in a few }\end{array}$ & $\begin{array}{l}\text { Concentrations of THg typically are }<0.020 \mu \mathrm{g} / \mathrm{L} \text { in streamwater } \\
\text { except in urban areas, where concentrations are as high as } \\
\text { samples from the SBAC substantially exceed regional concentra- } \\
\text { tions. MeHg concentrations in surface water - both streamwater and } \\
\text { reservoir water - have generally been found to be }<0.001 \mu \mathrm{g} / \mathrm{L} .\end{array}$ \\
$\begin{array}{l}\text { centrations were as high as } 0.250 \mu \mathrm{g} / \mathrm{L} \text {. Much of the THg in urban } \\
\text { areas was in particulate form. Concentrations of } \mathrm{MeHg} \text { exceeded } \\
0.002 \mu \mathrm{g} / \mathrm{L} \text { in some urban areas, but were }<0.001 \mu \mathrm{g} / \mathrm{L} \text { in forested } \\
\text { wetlands areas. }\end{array}$
\end{tabular}

\section{Summary and Conclusions}

Since the 1980s, total mercury (THg) has been found at contaminant levels in groundwater from the KirkwoodCohansey aquifer system in the New Jersey Coastal Plain. Studies of sources of the THg and its possible mobilization by anthropogenic inputs to the subsurface, such as discharges of septic-system effluent, are summarized in this report. Results of studies of contaminant levels of THg in soils, sediments, groundwater and surface water at the William J. Hughes Technical Center in Atlantic County, New Jersey, which may arise from former military activities, also are summarized. In comparing the levels of mercury found in various media at the William J. Hughes Technical Center (WJHTC) with those found regionally, the following conclusions can be made.

- Some total mercury (THg) concentrations in groundwater and streamwater at the WJHTC are low, similar to concentrations considered background levels (less than $0.01 \mu \mathrm{g} / \mathrm{L}$ and less than $0.1 \mu \mathrm{g} / \mathrm{L}$, respectively) for waters of the Coastal Plain region underlain by sediments of the Cohansey and Kirkwood Formations.
- THg in groundwater and streamwater at the WJHTC site is, however, found at concentrations that are highly variable.

- THg in groundwater and streamwater at the WJHTC site has been measured at concentrations that exceed the MCL for drinking water $(2 \mu \mathrm{g} / \mathrm{L})$ and the Surface Water Quality Standard of $0.05 \mu \mathrm{g} / \mathrm{L}$ but has not been found at the high concentrations (greater than $10 \mu \mathrm{g} / \mathrm{L}$ ) reported for some domestic-well waters in the region.

- Where THg is contributed by geologic and atmospheric deposition, regional levels of THg in soils and bed sediments are low (less than $0.1 \mathrm{mg} / \mathrm{kg}$ ).

- Regionally, where agricultural or urban inputs of THg appear likely, the THg contents of soils and sediments are, in a few instances, at levels (up to $12.2 \mathrm{mg} / \mathrm{kg}$ ) higher than those regarded as representative of background levels. 
- The levels of THg (up to $555 \mathrm{mg} / \mathrm{kg}$ ) found in soils and sediments of parts of the watershed of the South Branch of Absecon Creek (SBAC) greatly exceed those generally found in regional soil and streambed sediments.

- Because of channelization and other disturbances, it is likely that THg in the SBAC watershed has been mobilized; the original distribution probably has changed, and as a result of redistribution, $\mathrm{THg}$ contents of soil and sediment may not now (2012) be as high as they were when deposition took place.

- The THg contents of SBAC soils and sediments that are found at levels greatly exceeding regional levels may be indicative of a source at the WJHTC site other than the hypothesized regional THg sources.

It is not known whether the THg-contaminated ( $>2 \mu \mathrm{g} / \mathrm{L}$ ) groundwater from the residential areas that surround the WJHTC has contributed to the THg concentrations in shallow groundwater at the WJHTC. Concentrations of THg in groundwater at the WJHTC do not range as high as some of the concentrations found in domestic-well waters throughout the region. On the other hand, THg concentrations in several streamwater samples from the SBAC exceed those found, as of 2012, in other Coastal Plain streams. THg-rich runoff from contaminated soils bordering the SBAC may have led to the high concentrations in the streamwater.

\section{References Cited}

Academy of Natural Sciences, 1994, Preliminary assessment of total mercury concentrations in fish from rivers, lakes, and reservoirs in New Jersey: Philadelphia, Pa., Final Report 93-15F, 92 p.

Andersson, A., 1979, Mercury in soils, in Nriagu, J., ed., The biogeochemistry of mercury in the environment: Amsterdam, The Netherlands, Elsevier/North Holland Biomedical Press. p. 79-112.

Barkay, T., Gillman, M., and Turner, R.R., 1997, Effects of dissolved organic carbon and salinity on the bioavailability of mercury: Applied and Environmental Microbiology, v.63 p. $4267-4271$.

Barringer, J.L., MacLeod, C.L., and Gallagher, R.A., 1997, Mercury in ground water, soils, and sediments of the Kirkwood-Cohansey aquifer system in the New Jersey Coastal Plain: U.S.Geological Survey Open-File Report 95-475, $260 \mathrm{p}$.
Barringer, J.L., Szabo, Z., and Barringer, T.H., 1998, Arsenic and metals in soils in the vicinity of the Imperial Oil Company Superfund site, Marlboro Township, Monmouth County, New Jersey: U.S.Geological Survey WaterResources Investigations Report 98-4016, 251 p.

Barringer, J.L., and MacLeod, C.L., 2001, Relation of mercury to other chemical constituents in ground water in the Kirkwood-Cohansey aquifer system, New Jersey Coastal Plain, and mechanisms for mobilization of mercury from sediments to ground water: U.S. Geological Survey WaterResources Investigations Report 95-4230, 154 p.

Barringer, J.L., Szabo, Z., Kauffman, L.J., Barringer, T.H., Stackelberg, P.E., Ivahnenko, T., Rajagopalan, S., and Krabbenhoft, D.P., 2005, Mercury concentrations in water from an unconfined aquifer system, New Jersey Coastal Plain: Science of the Total Environment, v. 346, p. 169-183.

Barringer, J.L., Szabo, Z., Schneider, D., Atkinson, W.D., and Gallagher, R.A., 2006, Mercury in ground water, septage, leach-field effluent, and soils in residential areas, New Jersey Coastal Plain: Science of the Total Environment, v. 361, p. 144-162.

Barringer, J.L., and Szabo, Z., 2006, Overview of investigations into mercury in ground water, soils, and septage, New Jersey Coastal Plain: Water, Air, and Soil Pollution, v. 175, p. 193-221.

Barringer, J.L., Riskin, M.L., Szabo, Z., Reilly, P.A., Rosman, R., Bonin, J.L., Fischer, J.M., and Heckathorn, H.A., 2010a, Mercury and methylmercury dynamics in a Coastal Plain watershed, New Jersey, USA: Water, Air, and Soil Pollution, v. 212 , p. 251-273, DOI: $10.1007 / \mathrm{s} 11270-010-0340-1$.

Barringer, J.L., Szabo, Z., Reilly, P.A., Riskin, M.L., and Cenno, K., 2010b, Mobilization of mercury to a first-order Coastal Plain stream in New Jersey, [abs]: The Geological Society of America Northeastern and Southeastern Joint Meeting, 14-16 March, 2010, Abstracts with Programs, p. 154.

Barringer, J.L., Reilly, P.A., Eberl, D.D., Blum, A.E., Bonin, J.L., Rosman, R., Hirst, B., Alebus, M., Cenno, K., Gorska, M., 2011, Arsenic in sediments, groundwater, and streamwater of a glauconitic Coastal Plain terrain, New Jersey, USA - Chemical "fingerprints" for geogenic and anthropogenic sources: Applied Geochemistry, v. 26, p. 763-776.

Bollen, A., Wenke, A., and Biester, H., 2008, Mercury speciation analyses in $\mathrm{HgCl}_{2}$-contaminated soils and groundwater-Implications for risk assessment and remediation strategies: Water Research, v. 42, p. 991-1000. 
Bopp, R.F., 2005, Data analysis-Pilot-scale sediment core dating investigation, prepared for FAA William J. Hughes Technical Center, Atlantic City International Airport, New Jersey: Draft Report for TRC Environmental Corporation, January 2005, unpublished.

Brumbaugh, W.G., Krabbenhoft, D.P., Helsel, D.R., Wiener, J.G., and Echols, K.R., 2001. A national pilot study of mercury contamination of aquatic ecosystems along multiple gradients: Bioaccumulation in fish: U.S. Geological Survey Biological Science Report 2001-0009, 25 p.

Burton, E.D., Johnston, S.G., and Bush, R.T., 2011, Microbial sulfidogenesis in ferrihydrite-rich environments: Effects on iron mineralogy and arsenic mobility: Geochimica et Cosmochimica Acta, v. 75, p. 3072-3087.

Cauller, S.J., and Carleton, G.B., 2006. Hydrogeology and simulated effects of ground-water withdrawals, KirkwoodCohansey aquifer system, upper Maurice River basin area, New Jersey. U.S. Geological Survey Scientific Investigations Report 2005-5258. (Also available at http://pubs. er.usgs.gov/usgspubs/sir/sir20055258)

Clark, J.S., and Paulachok, G.N., 1989. Water levels in the principal aquifers of Atlantic County and vicinity, New Jersey, 1985-86: New Jersey Geological Survey Open-File Report 88-3, 33 p.

de la Rosa, D.A., Velasco, A., Rosas, A., and Volke-Sepúlveda, 2006, Total gaseous mercury and volatile organic compounds measurements at five municipal solid waste disposal sites surrounding the Mexico City Metropolitan Area: Atmospheric Environment, v. 40, p. 2079-2088.

Dooley, J.H., 1992, Natural sources of mercury in the Kirkwood-Cohansey aquifer system of the New Jersey Coastal Plain: New Jersey Geological Survey Report 27, 17 p.

Feng, X., Tang, S., Li, Z., Wang, S., and Liang, L., 2004, Landfill is an important atmospheric mercury emission source: Chinese Science Bulletin, v. 19, p. 2068-2072.

Gibs, J., Szabo, Z., Ivahnenko, T., Wilde, F.D., 2000, Change in field turbidity and trace-element concentrations during well purging: Ground Water, v. 38, p. 577-588.

Gilmour, C.C., and Henry, E.A., 1991, Mercury methylation in aquatic systems affected by acid deposition: Environmental Pollution, v. 71, p. 131-169.

Glass, G.E., Leonard, E.N., Chan, W.H., and Orr, D.B., 1986, Airborne mercury in precipitation in the Lake Superior region: Journal of Great Lakes Research, v. 12, no. 1, p. $37-51$.

Glass, G.E., Sorensen, J.A., Schmidt, K.W., Rapp, G.R., Yap, D., and Fraser, D., 1991, Mercury deposition and sources for the upper Great Lakes region: Water, Air, and Soil Pollution, v. 56, p. 235-249.
Greenberg, Wojtenko, I., Chen, H.W., Krivanek, S., Butler, J. Held, J., Weis, P., and Reiss, N., 1992, Mercury in air and rainwater in the vicinity of a municipal resource recovery facility in northwestern New Jersey: Air and Waste Management Association Meeting, Durham, N.C., May 1992.

Grigal, D.F., 2003, Mercury sequestration in forests and peatlands: Journal of Environmental Quality, v. 32, p. 393-405.

Guentzel, J.L., 2009, Wetland influences on mercury transport and bioaccumulation in South Carolina: Science of the Total Environment, v. 407, p. 1344-1353.

Haitzer, M., Aiken, G.R., and Ryan, J.N., 2002, Binding of mercury (II) to dissolved organic matter: the role of the mercury-to-DOM concentration ratio: Environmental Science and Technology, v. 36, p. 3564-3570.

Hogg, T.J., Stewart, J.W.B., and Bettany, J.R., 1978, Influence of the chemical form of mercury on its adsorption and ability to leach through soil: Journal of Environmental Quality, v. 7, p. $440-444$

Hurley, J.P., Benoit, J.M., Babiarz, C.L., Shafer, M.M., Andren, A.W., Sullivan, J.R., Hammond, R., and Webb, D.A., 1995, Influences of watershed characteristics on mercury levels in Wisconsin rivers: Environmental Science and Technology, v. 29, p. 1867-1875.

Johnsson, P.A., and Barringer, J.L., 1993, Water quality and hydrogeochemical processes in McDonalds Branch basin, New Jersey Pinelands, 1984-88: U.S. Geological Survey Water-Resources Investigations Report 91-4081, 111 p.

Kauffman, L.J., Baehr, A.L., Ayers, M.A., Stackelberg, P.E., 2001, Effects of land use and travel time on the distribution of nitrate in the Kirkwood-Cohansey aquifer system in southern New Jersey: U.S. Geological Survey WaterResources Investigations Report 01-4117. 49 p. (Also available at http://pubs.er.usgs.gov/usgspubs/wril wri20014117)

Kim, K-H., and Kim, M-Y., 2002, Mercury emissions as landfill gas from a large-scale abandoned landfill site in Seoul: Atmospheric Environment, v. 36, p. 4919-4928.

Kolka, R.K., Nater, E.A., Grigal, D.F., and Verry, E.S., 1999, Atmospheric inputs of mercury and organic carbon into a forested uplan/bog watershed: Water, Air, and Soil Pollution, v. 133, p. 273-294.

Koterba, M.T., Andres, A.S., Vrabel, J., Crilley, D.M., Szabo, Z., DeWild, J.T., Aiken, G.R., and Reyes-Padro, B., 2006, Occurrence and distribution of mercury in the surficial aquifer, Long Neck peninsula, Sussex County, Delaware, 2003-04: U.S. Geological Survey Scientific Investigations Report 2006-5011, $171 \mathrm{p}$. 
Kozinski, J., Szabo, Z., Zapecza, O.S., and Barringer, T.H., 1995, Natural radioactivity in, and inorganic chemistry of, ground water in the Kirkwood-Cohansey aquifer system in southern New Jersey, 1983-89: U.S. Geological Survey Water-Resources Investigations Report 92-4144, 130 p.

Krabbenhoft, D.P., Benoit, J.M., Babiarz, C.L., Hurley, J.P., and Andren, A.W., 1995, Mercury cycling in the allaquash Creek watershed, northern Wisconsin: Water Air, and Soil Pollution, v. 80, p. 425-433.

Lindberg, S.E., 1987, Emission and deposition of atmospheric mercury vapor, chapter 8-Lead, mercury, cadmium, and arsenic in the environment: New York, John Wiley and Sons, $18 \mathrm{p}$.

Markley, M.L., 1979, Soil series of the Pine Barrens, in Forman, R.T.T., ed., Pine Barrens - ecosystem and landscape: New York, Academic press, p. 81-93.

Merck, 1983, The Merck Index: Rahway, New Jersey, Merck and Co., Inc., 1,463 p.

Mierle, G., and Ingram, R., 1991, The role of humic substances in the mobilization of mercury from watersheds: Water, Air, and Soil Pollution, v. 56, p. 349-357.

Modica, E., Buxton, H.T., and Plummer, L.N., 1998, Evaluating the source area and residence times of ground-water seepage to streams, New Jersey Coastal Plain: Water Resources Research, v. 34, p. 2797-2810.

Murphy, E., Dooley, J., Windom, H.L., and Smith, R.G., Jr., 1994. Mercury species in potable ground water in southern New Jersey: Water, Air, and Soil Pollution, v. 78, 61-72.

Murphy, E.A., and Aucott, M., 1998, An assessment of the amounts of arsenical pesticides used historically in a geographical area: Science of the Total Environment, v. 218, p. $89-101$.

Murphy, E.A., and Aucott, M., 1999, A methodology to assess the amounts of pesticidal mercury used historically in New Jersey: Journal of Soil Contamination, v. 8, p. 131-148.

New Jersey Department of Environmental Protection, 2010, Surface water quality standards: Trenton, N.J., New Jersey Department of Environmental Protection, N.J.A.C.7:9B, accessed at http://www.state.nj.us/dep/wms/bwqsa/swqs. htm.

New Jersey Department of Environmental Protection, 2005, Federal and New Jersey Drinking Water Standards: Trenton, N.J., New Jersey Department of Environmental Protection, accessed at http://www. state.nj.us/dep/watersupply/standard.htm.

Nriagu, J.O., and Pacyna, J.M., 1988, Quantitative assessment of worldwide contamination of air, water, and soils by trace metals: Nature, v. 333, p. 134-139.
O’Neil, M.J., 2006, ed., Merck Index (14th ed.): Whitehouse Station, N.J., Merck and Co., Inc., p. 1017-1018.

Parkhurst, D.L., and Appelo, C.A.J., 1999, User's guide to PHREEQE (version 2) - a computer program for speciation, batch reaction, one-dimensional transport, and inverse geochemical calculations: U.S. Geological Survey WaterResources Investigations Report 99-4259, 327 p.

Poelstra, P., Frissel, M.J., Van Du Klug, N., and Tap, W., 1974, Behaviour of mercury compounds in soils-Accumulation and evaporation, in comparative studies of food and environmental contamination: Vienna Austria, International Atomic Energy Agency, United Nations Proceedings Series IAEA-SM-175/46, p. 281-292.

Reilly, P.A., Barringer, J.L., and Szabo, Z., 2012 Mobility of mercury in disturbed soils within the New Jersey Coastal Plain: Geological Society of America Northeastern Section Meeting, Program with Abstracts, Hartford, CT, March 2012, p. 118.

Rhodehamel, E.C., 1970, A hydrologic analysis of the New Jersey Pine Barrens region: Trenton, N.J., New Jersey Division of Water Policy and Water Resources, Circular No. 22, $35 \mathrm{p}$.

Rhodehamel, E.C., 1979, Geology of the Pine Barrens of New Jersey, in Forman, R.T.T., ed., Pine Barrens - ecosystem and landscape: New York, Academic press, p. 39-60.

Ryan, J.N., and Gschwend, P.M., 1994, Effect of solution chemistry on clay colloid release from an iron oxide-coated aquifer sand: Environmental Science and Technology, v. 28, p.1717-1726.

Shanley, J.B., Mast, M.A., Campbell, D.H., Aiken, G.R., Krabbenhoft, D.P., Hunt, R.J., Walker, J.F., Schuster, P.F., Chalmers, A., Aulenbach, B.T., Peters, N.E., MarvinDiPasquale, M., Clow, D.W., and Shafer, M.M., 2008, Comparison of total mercury and methylmercury cycling at five sites using the small watershed approach: Environmental Pollution, v. 154, p. 143-154.

Schmidt, H.G., 1973, Agriculture in New Jersey: New Brunswick, N.J., Rutgers University Press, 335 p.

Slemr, F., and Langer, E., 1992, Increase in global atmospheric concentrations of mercury inferred from measurements over the Atlantic Ocean: Science, v. 355, p. 434-437.

Szabo, Z., Oden, J.H., Gibs, J., Rice, D.E., and Ding, Y., 2002, Variation in aluminum, iron, and particle concentrations in oxic ground-water samples collected by use of tangentialflow filtration with low-flow sampling: Proceedings of International Society for Optical Engineering 4575, Newton (MA), Chemical and biological early warning monitoring for water, food, and ground, 2001, p. 42-61. 
Szabo, Z., DePaul, V.T., Kraemer, T.F., and Parsa, B. 2005, Occurrence of radium-224, radium-226, and radium-228 in water of the unconfined Kirkwood-Cohansey aquifer system, southern New Jersey: U.S. Geological Survey Scientific Investigations Report 2004-5224, 92 p.

Szabo, Z., Jacobsen, E., Kraemer, T.F., and Parsa, B., 2008, Concentrations and environmental fate of Ra in cationexchange regeneration brine waste disposed to septic tanks and accumulation in sludge, New Jersey Coastal Plain, U.S.A: Journal of Environmental Radioactivity, no. 99, p. $947-965$.

Szabo, Z., Jacobsen, E., Kreaemer, T.F., and Parsa, B., 2010a, Environmental fate of $\mathrm{Ra}$ in cation-exchange regeneration brine waste disposed to septic tanks, New Jersey Coastal Plain, U.S.A.: Migration to the water table: Journal of Environmental Radioactivity, v. 101, p. 33-44.

Szabo, Z., Barringer, J.L., Jacobsen, Eric, Smith, N.P., Gallagher, R.A., and Sites, Andrew, 2010b, Variability of mercury concentrations in domestic-well water, New Jersey Coastal Plain: The Geological Society of America Joint Northeastern and Southeastern Meeting, 2010, Abstract with Programs, p. 178.

The Chlorine Institute, Inc., 2000, Guidelines for technologies to reduce mercury in sodium hydroxide: Industry report, accessed February 11, 2012, at http://www.epa.gov/Region5/ mercury/.

TRC, 2005, Documentation of Navy contributions to mercury impacts on Area U, North and South Branches of Absecon Creek watershed: Consultant's report, unpublished.

TRC, 2006, Draft Area U—Supplemental remedial investigation/ecological risk assessment report: Draft consultant's report, June 2006, unpublished.

TRC, 2010, Documentation of relationship between mercury sediment contamination and impacts to the Area B groundwater remediation system: Consultant's report, October 2010, unpublished.

Wacker, P.O., 1979, Human exploitation of the New Jersey Pine Barrens before 1900, in Forman, R.T.T., ed., Pine Barrens: Ecosystem and Landscape: New York, Academic Press, p. 3-23.

Weston Solutions, 2009, Draft final interim supplemental remedial investigations mercury contamination at Area U: Draft consultant's report, May 2009, unpublished.

Wiatrowski, H.A., Das, S., Kukkadapu, R, Ilton, E.S., Barkay, T., and Yee, N. 2009, Reduction of Hg (II) to Hg (0) by magnetite: Environmental Science and Technology, v. 43, p. 5307-5313.
Windom, H.L., and Smith, R.G., 1992, analysis of mercury species in ground water using inductively coupled plasmamass spectrometry and gas chromatography-Final Report to New Jersey Department of Environmental Protection, Division of Science and Research: Trenton, N.J., unpublished report, $32 \mathrm{p}$.

Wolf, D.E., and Engel, R.E., 1948, Killing turf weeds with chemicals: New Brunswick, N.J., Rutgers University, Circular 513.

Wu, F., Cai, Y., Evans, D., and Dillon, P., 2004, Complexation between $\mathrm{Hg}$ (II) and dissolved organic matter in stream waters: An application of fluorescence spectroscopy: Biogeochemistry, v. 71, p. 339-351.

Yudovich, Ya., E., and Ketris, M.P., 2008, Mercury in coal: A review, Part 1. Geochemistry: International Journal of Coal Geology, v. 62, p. 107-134.

Yuretich, R.F., Crerar, D.A., Kinsman, D.J., and Borcsik, M.P., 1981, Hydrogeochemistry of the New Jersey Coastal Plain. 1. Major element cycles in precipitation and river water: Chemical Geology, v. 22, p. 1-23.

Zapecza, O.S., 1989, Hydrogeologic framework of the New Jersey Coastal Plain: U.S. Geological Survey Professional Paper 1404-B, 49 p., 24 pl. 
Prepared by the West Trenton Publishing Service Center

For additional information, write to:

Director

U.S. Geological Survey

New Jersey Water Science Center

Mountain View Office Park

810 Bear Tavern Rd., Suite 206

West Trenton, NJ 08628

or visit our Web site at:

http://nj.usgs.gov/ 


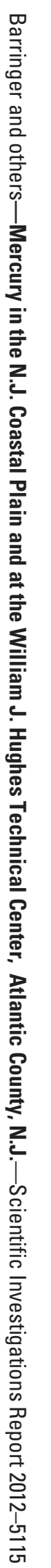

